\title{
A 3000-Year Culture Sequence from Palau, Western Micronesia
}

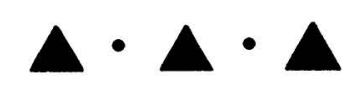

GEOFFREY R. CLARK

The SETtLement of WESTERn Micronesia is often considered to result from an early Austronesian population movement from Island Southeast Asia that predates the Lapita dispersal and marks the first crossing of the substantial sea gaps necessary to occupy the islands of Remote Oceania (Green 1991). For these reasons much research has focused on the origin, timing, and pattern of prehistoric colonization (Kirch 2000:175).

Osborne (1958:163) hypothesized that the linear alignment of western Micronesian islands could have allowed them to act as "stepping stones" for the essentially synchronous colonization of Palau, Yap, and the Marianas between 3750 and 3250 B.P. (Osborne 1958:164, 1966:464). The "stepping stone" model was, however, falsified by field data, which had the oldest prehistoric sites dating to 3500 B.P. in the northern Marianas Islands, while the earliest sites in Palau and Yap had radiocarbon ages going back to only 2000 B.P. The general consensus arising from the archaeological data was that each archipelago was likely to have been colonized at different times by distinct groups from an already culturally disparate Austronesian population in Island Southeast Asia (Intoh 1997; Masse 1990; Rainbird 1994).

As Irwin (1992:126) has noted, though, it is anomalous that the Marianas, which are almost twice the distance from insular Asia than Palau and Yap, were settled 1500 years before them. Further, early colonization of the Marianas suggests an early maritime ability that was sufficient to cross a $2200-\mathrm{km}$ sea gap from the Philippines (Blust 2000; Shutler 1999:527; Wickler 2001:185), but which failed, or was not employed, to reach other parts of western Micronesia-islands that are closer to each other than they are to insular Asia-or to volcanic islands lying farther east, such as Chuuk and Pohnpei (Figure 1).

Recent palaeoecological and archaeological work now demonstrates that all of western Micronesia was occupied before 2000 B.P., with two colonization chronologies proposed. Colonization is generally agreed to be archaeologically visible in the Marianas by 3500 cal. B.P. (Butler 1994), but recent critical reviews of radiocarbon ages from cultural deposits in Palau and the Marianas suggest human arrival might occur later, at ca. 3300-3000 B.P. (Clark 2004; Phear et al. 2003). A 


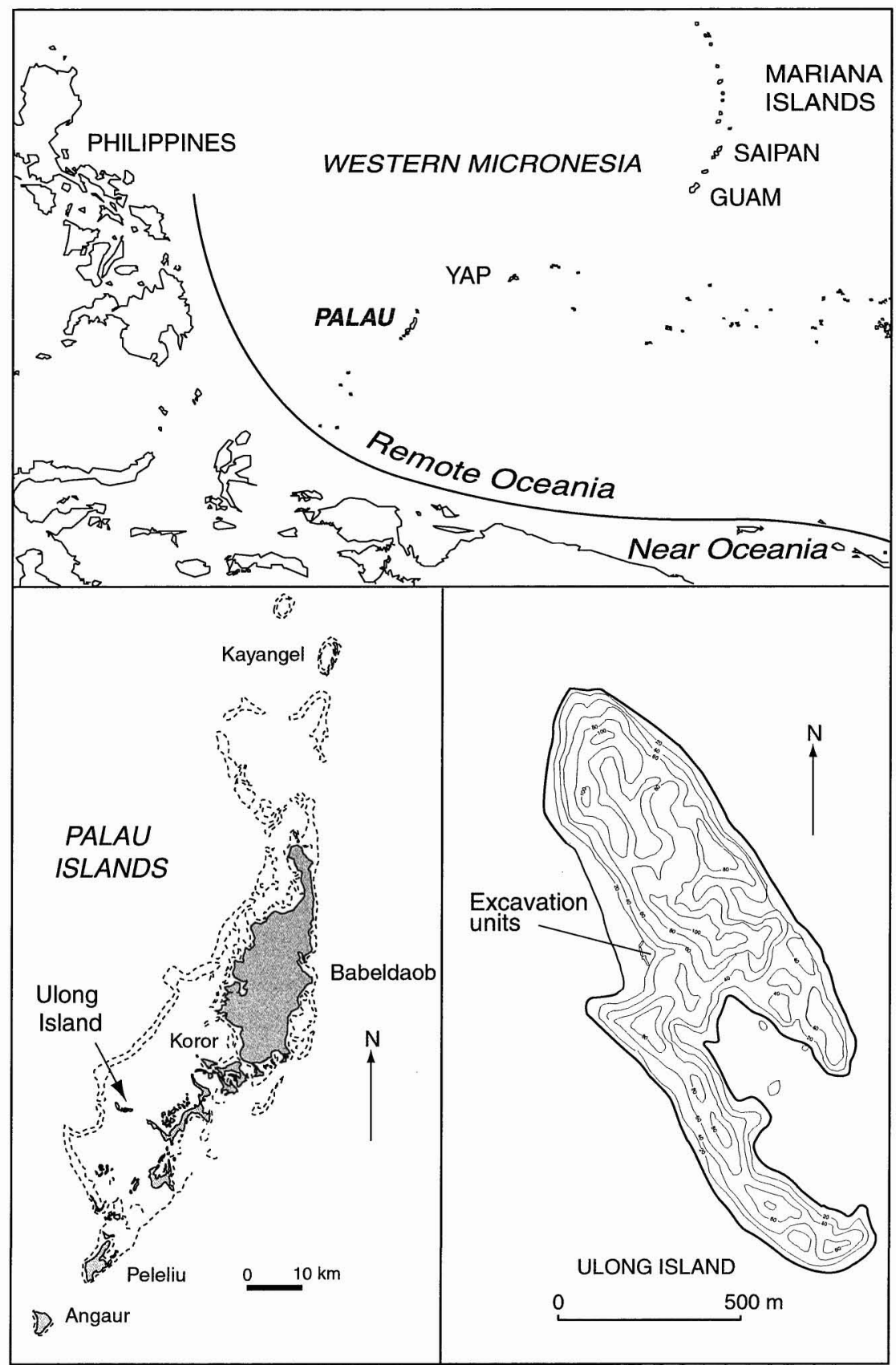

Fig. 1. Map of western Micronesia, Palau, and Ulong Island.

much longer history of human occupation, with settlement of the Marianas at 4300 B.P. (Athens and Ward 2004) and Palau at 4500 B.P., has been tentatively outlined from paleoenvironmental data, including most notably the presence of swamp taro pollen (Cyrtosperma chamissonis) from the Ngerchau core in Palau 
(Athens and Ward 2001; Wickler 2001). A significant point of difference between the two scenarios is that colonization of western Micronesia 3500-3000 cal. B.P. is consistent with settlement by Austronesian speakers whereas the earlier age estimates might reflect either proto-Austronesian or non-Austronesian colonization.

The current disparity between age estimates for human arrival in western Micronesia can best be resolved by an integrated program of archaeological and paleoenvironmental research (see Athens and Ward 1999, 2001; Welch 2001; Wickler 2001). Whichever chronology is eventually supported, it is clear that western Micronesia's colonization and settlement history is currently in a state of flux. For instance, as they currently stand, both "long" (ca. 4500-4300 B.P.) and "short" (ca. 3500-3000 B.P.) chronologies imply the discovery and settlement of Palau, Yap, and the Marianas was relatively rapid within 200-500 years, restoring Osborne's stepping stone theory as a plausible model of island colonization from populations either to the north or south of western Micronesia (e.g., Oda 1981: Fig. 10; Osborne 1958).

Assumptions about the rate, content, and cause of prehistoric culture change require reassessment now that the chronological span for human occupation in western Micronesia has been extended well beyond 2000 B.P. In Palau and Yap the issue is most acute because even the acceptance of a short chronology extends their prehistoric sequences by a millennium, and attempts to examine culture change have been hampered by a deficiency of well-dated and well-stratified deposits containing early and late sets of prehistoric remains, particularly ceramics (Kirch 2000: 175; Wickler 2001:190).

This paper reports a 3000-year-old culture sequence from Ulong Island in the Republic of Palau. The Ulong archaeological sequence, like several from the $\mathrm{Pa}$ cific that span millennia, has been affected by marine events, such as sea-level change and tropical storms (e.g., Best 2002:17), and variation in the intensity and duration of site use. No single sequence, of course, will contain all the material-culture variability from an archipelago, and from ca. 2000 to 1000 B.P. the Ulong sequence may be truncated. However, the recovery of ceramics and other items securely dated to $3000-2400 \mathrm{cal}$. B.P. is an important addition to the archaeological record of Palau, where the oldest reliably dated pottery so far reported has an age of ca. 2400 B.P. (Welch 2002).

The oldest radiocarbon dates and summary excavation data have been published (Clark 2004; Clark and Wright 2003a), but here I present detailed descriptions of the ceramics, along with new radiocarbon determinations, compositional examination of artifacts, and analysis of fauna. Previous attempts to identify chronologically diagnostic traits in Palauan pottery assemblages have been largely unsuccessful (Osborne 1979:236; Snyder 1989; Welch 2001:182; Wickler et al. 1998). As a result, it has been unclear whether ceramics were stylistically conservative in prehistory or if the uniformity reflected an archipelagic archaeological record that was incomplete (Desilets et al. 1999; Lucking 1984; Osborne 1979; Takayama 1981:4).

The degree of temporal change evident in the Ulong ceramic sequence now suggests that the latter view is correct, necessitating a more dynamic view of Palau's prehistoric material culture and settlement history than has hitherto been the case (e.g., Intoh 1992; Osborne 1979). Such a perspective is also compatible with the degree of prehistoric landscape transformations documented on Babel- 
daob (Athens and Ward 1999, 2001; Welch 2001; Wickler 2002) and more generally with the cultural complexity suggested by linguistic and biological studies of western Micronesian populations (Blust 2000; Devlin et al. 2001; Lum and Cann 2000).

\section{ULONG ISLAND}

Ulong consists of several small raised limestone islands lying $27 \mathrm{~km}$ southwest of the main volcanic island of Babeldaob (Figure 1). Ulong belongs to the westernmost of the Chelbacheb group of Rock Islands, which are characterized by a steep and eroded topography, an absence of perennial streams, and shallow infertile soils derived from coralline beach sands (Corwin et al. 1956).

Prehistoric remains are concentrated on a large beach flat on the northern island (Figure 1). Douglas Osborne (1966, 1979) surveyed and excavated on the beach flat in 1954 and 1969, focusing his investigations at an area called Aulong 1 Wall Test, now registered as the traditional village site B: OR-15-5 (Snyder and Butler 1997).

Excavation of a $1.5 \mathrm{~m}$ by $4.6 \mathrm{~m}$ trench behind a section of prehistoric limestone wall in 1969 recovered pottery and midden to $1.3 \mathrm{~m}$ depth. Two ceramic assemblages were identified. The lowest rims were from simple bowls and everted jars (termed "back curve" by Osborne) with thin vessel walls that were described as "totally different" from an overlying thick-walled flange rim assemblage (Osborne 1979:76, Fig. 58). Seriation of ceramic attributes and attempts to directly date Ulong pottery with radiocarbon were unsuccessful, although Osborne $(1979: 75,76)$ considered that the basal ceramics represented an early prehistoric occupation. However, he was uncertain whether the 1969 excavation had reached the base of the cultural deposit (Osborne 1979:58, 271).

Reports of a thin blackware on Babeldaob dated to 2400-1700 B.P. (Welch $2001: 182$ ), and less securely to 3400-3000 B.P. (Athens and Ward 2001:165; Welch 2001:180), invited new excavations to sample and date the thin-walled ceramics recorded previously by Osborne.

There were several advantages in excavating the coralline lime sands of Ulong. First, the beach flat deposit evidently contained archaeological materials suitable for radiocarbon dating with conventional or AMS methods. On Babeldaob the selection of dating samples is made difficult by the subsurface presence of naturally occurring oxidized plant fragments in clay deposits that could potentially be taken to be archaeological charcoal, and strongly acid soils that chemically attack dateable materials such as bone and marine shell (Anderson et al. in press; Athens and Ward 1999; Desilets et al. 1999).

Second, the area investigated by Osborne could have potentially been attractive to early colonists. Before the sand plain prograded and attained its modern dimensions, the location would have been a sheltered embayment below an eroded limestone slope that gave access to other parts of the island.

\section{EXCAVATION AND STRATIGRAPHY}

The position of Osborne's 1968 Wall Test excavation was located, and a $1 \mathrm{~m}^{2}$ test pit called TP.1 was placed immediately east of it to determine where the intact 


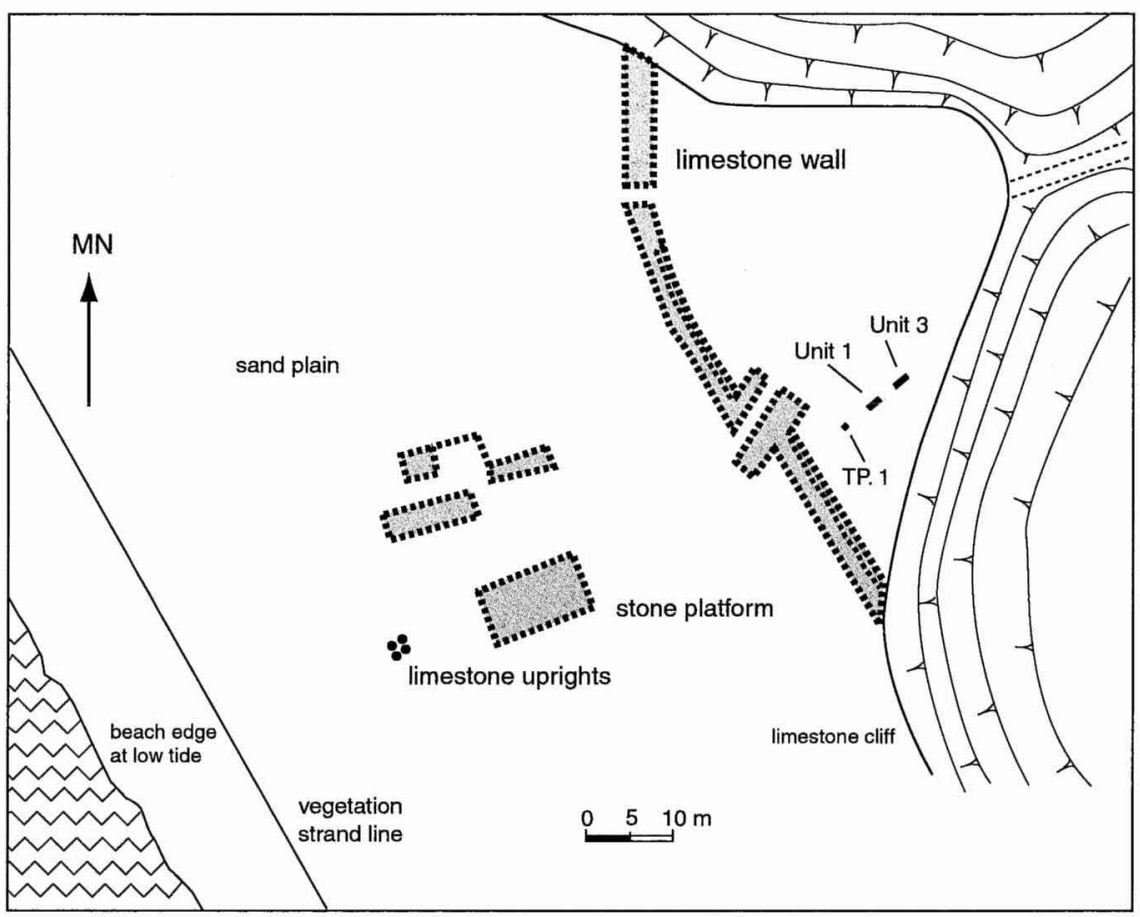

Fig. 2. Plan of Ulong Island excavations and location of stone work features associated with traditional village occupation.

deposits began (Figure 2). East of TP.1, two $1 \mathrm{~m}$ by $2 \mathrm{~m}$ units were placed at each end of an $11 \mathrm{~m}$ transect. Unit 1 was the eastern unit and Unit 3 the western unit (Figures 2 and 3). Unit 3 is $100 \mathrm{~m}$ from the beach and ca. $3.2 \mathrm{~m}$ above high tide level.

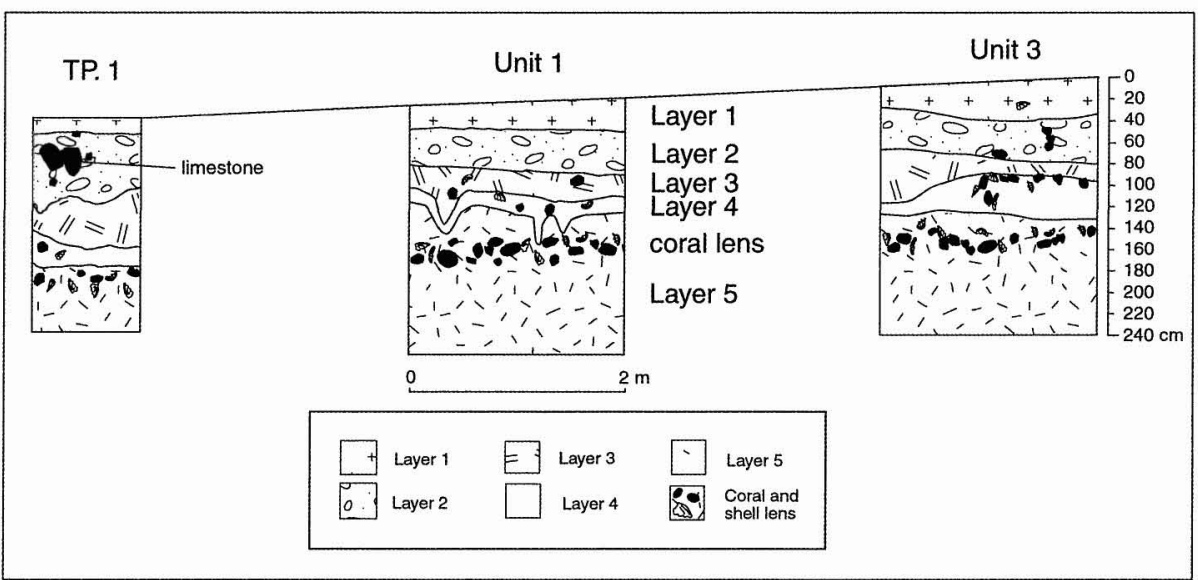

Fig. 3. Excavation stratigraphy of TP.1, Unit 1, and Unit 3. 
Excavation was by $10 \mathrm{~cm}$ spit within natural layers with sediments screened through $5 \mathrm{~mm}$ mesh. Retention of cultural materials was adequate in sandy levels but was compromised in upper levels by the sticky, silty sediment. The stratigraphy was relatively simple with organic content and silt particles highest in upper layers, while the amount of calcareous sand increased with depth (Figure 3). The coralline lime sands were highly alkaline with $\mathrm{pH}$ readings from 8.0 to 10.5 . Stratigraphy was similar in all excavations with five layers identified, although individual layer thickness varied considerably within units (Figure 3). Excavations continued to $2.2 \mathrm{~m}$ below surface with shovel tests and a sand auger used to 3.25 $m$ depth.

Layer 1: 0-40 cm. Very dark-brown fine-medium silty clay (10YR $3 / 2$, $\mathrm{pH}=8.0-8.5)$ grading to a gray-brown fine-medium silty sand (10YR 5/1, $\mathrm{pH}=8.5-9.0)$. Abundant thick-walled ceramics and fish bone, but little charcoal or marine shell.

Layer 2: 40-80 cm. Light gray ashy soil in upper margins grading to a light redbrown fine-medium silty soil (10YR $5 / 3, \mathrm{pH}=8.5-9.0)$. Less pottery and fish bone compared with Layer 1.

Layer 3: 80-100/110 cm. Very dark-gray medium silty sand (10YR 3/1, $\mathrm{pH}=8.5-9.0)$. Shellfish and charcoal fragments in association with pottery.

Layer 4: 100/110-135 cm. Light gray-brown medium calcareous sand (10YR $6 / 2, \mathrm{pH}=9.0)$. Some large sherds, stone artifacts and complete shellfish remains in the layer, but few ceramics.

Layer 5: 135-220 cm. Yellow-white medium sand (10YR 8/1, pH = 9.510.5). Shellfish remains were abundant and the amount of pottery and fish bone decreased with depth.

Layer 6: 220-325 cm. Pale yellow-white medium sand (10YR 8/1, pH $=9.5-$ 10.5). Cultural material was absent except for a few potsherds and shellfish at 240 cm depth.

The major stratigraphic division was between an upper deposit containing quantities of silty clay (Layer 1 to Layer 3) and a lower deposit composed of calcareous lime sand (Layer 4 to Layer 6). The division appears to represent the development of a stable beach flat, due to sea-level fall or a prograding shoreline, on which permanent vegetation cover was established. Expansion of the beach flat appears to coincide with increased human activity in the upper layers (Layers 1-3), possibly the result of permanent/semipermanent occupation, and a greater frequency of site use or larger group size. This is suggested by a substantial increase in pottery deposition with sherd numbers and sherd weights more than doubling in the five spits above the stratigraphic transition $(110-100 \mathrm{~cm}$ to $60-70 \mathrm{~cm})$ than in the five spits below $(110-120 \mathrm{~cm}$ to $150-160 \mathrm{~cm})$. Features including scoop hearths, pits, and possible stake holes were also recorded in Layer 4. The extent of the most recent occupation is visible in abundant surface scatters of pottery and marine shell, limestone platforms walls, burials, and a walk-in well (Osborne 1979). A discontinuous lens of unbound coral and large shellfish remains occurred in Layer 5 at ca. $140-170 \mathrm{~cm}$. The lens of rounded coral fragments might represent cyclone or storm surge activity, but as Craib and Mangold (1999) note, although archaeologists working in coastal areas frequently attribute stratigraphic anomalies to storm activity, there is little evidence that such deposits are a significant source of beach sediment. Rasser and Riegl (2002) attribute some 
coral rubble deposits to sea-level changes during the Holocene from the erosion of subaerially exposed reefs, which were then transported by storms, and it is also possible that coral rubble was brought by people to stabilize the intertidal beach surface. Geoarchaeological work is required to resolve this issue. Ceramics, bone, and marine shell were excavated down to $220 \mathrm{~cm}$, with sparse amounts of ceramic and marine shell recovered from $240 \mathrm{~cm}$ depth.

\section{RADIOCARBON DATING}

A total of 22 radiocarbon determinations comprising 11 AMS and 11 conventional results were obtained on carbonized residues adhering to potsherds (10), charcoal fragments (5), and marine shells (7). Samples were subject to standard ABA pretreatment to remove contaminants. The chemical composition of pot residues was first examined with the electron microprobe and the results compared to a reference charcoal, black pottery, manganese nodule, and lignite to determine that pot residue/charcoal samples contained significant amounts of carbon.

Conventional dates were made at the radiocarbon dating laboratory of Australian National University using the benzene synthesis/liquid scintillation method. AMS samples were dated with the heavy ion accelerator at the Department of Physics, ANU, and the tandem accelerator at the Australian Nuclear Science and Technology Organisation. The large standard errors of seven ANU AMS dates result from the characteristics of the accelerator when measuring ${ }^{14} \mathrm{C}$ and do not reflect samples with low carbon yields (John Chappell, Earth Sciences, ANU, pers. comm.). Calibrations were made with the CALIB rev.4.3 software using method A at two standard deviations and the bidecadal curves for charcoal determinations of Stuiver and Reimer (1993) and Stuiver and Braziunas (1993) with $\Delta \mathrm{R}$ set at 0 for marine dates.

The four oldest dates obtained with AMS (ANU-11765, ANU-11763, ANU11762, ANU-11792) produced unusually early ages as a result of laboratory contamination and are therefore rejected (see Clark 2004 for details). The remaining 18 determinations are listed separately in Table 1 . The dates fall into two groups, with the smaller group containing four determinations from the top $60 \mathrm{~cm}$ (Layer 1 and 2), which have median calibrated ages ranging from 580 to 940 cal. B.P. Results on charcoal and a pot residue have a similar calibrated span to the marine shell ages. These dates are consistent with Masse's (1990) estimate for the establishment of "traditional" stonework villages in the Rock Islands, but slightly earlier than the 600 cal. B.P. date recently suggested by Phear et al. (2003).

There are 13 results with median ages ranging from ca. 3000 to $2400 \mathrm{cal}$. B.P., which date sediments between $220 \mathrm{~cm}$ and $80 \mathrm{~cm}$ depth (Table 1). The two oldest results on shell (ANU-11766, ANU-11934) are from $220 \mathrm{~cm}$ depth, and they, along with an AMS date on charcoal potentially displaced from lower levels (OZG-324), indicate human activity at $3000 \mathrm{cal}$. B.P. Of the remaining ages, six on marine shell are from spits between $70-80 \mathrm{~cm}$ and $150-160 \mathrm{~cm}$ and have a narrow span of ca. 2700-2300 cal. B.P. (ANU-12107, ANU-12108, ANU11933, ANU-11768, ANU-11769, ANU-11767), indicating a rapidly accumulating cultural deposit. Charcoal and pot residue determinations are similar to marine shell age ranges, but the two ANU AMS results (ANU-11931, ANU- 
Table i. Radiocarbon Dates from Ulong Island Excavations

\begin{tabular}{|c|c|c|c|c|c|}
\hline $\begin{array}{l}\text { LABORATORY } \\
\text { NO. }\end{array}$ & CRA & $\begin{array}{l}\text { CAL. B.P. } \\
\text { 2STD }\end{array}$ & ${ }^{13} \mathrm{C}$ & SAMPLE & CONTEXT \\
\hline \multicolumn{6}{|l|}{ Rejected } \\
\hline ANU-11765 & $3150 \pm 90$ & $\begin{array}{l}3630(3370) \\
3080\end{array}$ & $-24 \pm 0.2$ & Pot residue & $\begin{array}{l}\text { Unit 3: } 110-120 \mathrm{~cm} \text {, } \\
\text { Layer } 4\end{array}$ \\
\hline ANU-11792 & $3790 \pm 80$ & $\begin{array}{c}4420(4150) \\
3930\end{array}$ & $-24.0 \pm 2.0 \mathrm{E}$ & Charcoal & $\begin{array}{l}\text { Unit 3: } 120-130 \mathrm{~cm} \text {, } \\
\text { Layer } 4\end{array}$ \\
\hline ANU $-11763^{\dagger}$ & $3450 \pm 130$ & $\begin{array}{c}4090(3690) \\
3390\end{array}$ & $-26.7 \pm 0.2$ & Charcoal & $\begin{array}{l}\text { Unit 3: } 150-160 \mathrm{~cm} \text {, } \\
\text { Layer } 5\end{array}$ \\
\hline ANU-11762 & $4330 \pm 90$ & $\begin{array}{l}5280(4870) \\
\quad 4650\end{array}$ & $-26.8 \pm 0.2$ & Pot residue & $\begin{array}{l}\text { Unit 1: } 150-160 \mathrm{~cm} \text {, } \\
\text { Layer } 4\end{array}$ \\
\hline \multicolumn{6}{|l|}{ Accepted } \\
\hline ANU-11932 & $1070 \pm 70$ & $\begin{array}{c}740(640) \\
520\end{array}$ & $0.0 \pm 2.0 \mathrm{E}$ & Tridacna sp. & $\begin{array}{l}\text { TP.1: } 10-20 \mathrm{~cm} \text {, } \\
\text { Layer } 1\end{array}$ \\
\hline ANU-12097 & $660 \pm 150$ & $\begin{array}{l}920\left(580^{*}\right) \\
340\end{array}$ & $-24.0 \pm 2.0 \mathrm{E}$ & Charcoal & $\begin{array}{l}\text { TP.1: } 20-30 \mathrm{~cm} \text {, } \\
\quad \text { Layer } 1\end{array}$ \\
\hline ANU-12096 & $1400 \pm 60$ & $\begin{array}{c}1060(940) \\
820\end{array}$ & $0.0 \pm 2.0 \mathrm{E}$ & Hippopus sp. & $\begin{array}{l}\text { TP.1: } 20-30 \mathrm{~cm} \text {, } \\
\quad \text { Layer } 4\end{array}$ \\
\hline $\mathrm{OZG} 276^{\dagger}$ & $940 \pm 50$ & $\begin{array}{l}950\left(830^{*}\right) \\
730\end{array}$ & -23.2 & Pot residue & $\begin{array}{l}\text { Unit } 3: 50-60 \mathrm{~cm} \text {, } \\
\text { Layer } 2\end{array}$ \\
\hline ANU-11930 ${ }^{\dagger}$ & $1790 \pm 190$ & $\begin{array}{l}2150(1710) \\
1300\end{array}$ & $-24.0 \pm 2.0 \mathrm{E}$ & Charcoal & $\begin{array}{l}\text { Unit } 3: 70-80 \mathrm{~cm} \text {, } \\
\text { Layer } 2\end{array}$ \\
\hline ANU-12107 & $2830 \pm 70$ & $\begin{array}{l}2740\left(2620^{*}\right) \\
2350\end{array}$ & $0.0 \pm 2.0 \mathrm{E}$ & Tridacna sp. & $\begin{array}{l}\text { Unit 1: } 70-80 \mathrm{~cm} \text {, } \\
\text { Layer } 2\end{array}$ \\
\hline ANU-12108 & $2820 \pm 80$ & $\begin{array}{l}2750(2600) \\
\quad 2330\end{array}$ & $0.0 \pm 2.0 \mathrm{E}$ & Tridacna sp. & $\begin{array}{l}\text { Unit } 1: 80-90 \mathrm{~cm} \text {, } \\
\text { Layer } 3\end{array}$ \\
\hline ANU-11933 & $2890 \pm 110$ & $\begin{array}{l}2870(2700) \\
2340\end{array}$ & $0.0 \pm 2.0 \mathrm{E}$ & Conus sp. & $\begin{array}{l}\text { Unit 3: } 120-130 \mathrm{~cm} \text {, } \\
\text { Layer } 4\end{array}$ \\
\hline OZG342 ${ }^{\dagger}$ & $2820 \pm 40$ & $\begin{array}{l}3060(2910) \\
2790\end{array}$ & -24.9 & Charcoal & $\begin{array}{l}\text { Unit 3: } 120-130 \mathrm{~cm} \text {, } \\
\text { Layer } 4\end{array}$ \\
\hline ANU-11768 & $2890 \pm 50$ & $\begin{array}{l}2750(2700) \\
2450\end{array}$ & $2.5 \pm 0.2$ & Tridacna sp. & $\begin{array}{l}\text { Unit 3: } 140-150 \mathrm{~cm} \text {, } \\
\text { Layer } 5\end{array}$ \\
\hline ANU-11769 & $2950 \pm 50$ & $\begin{array}{l}2800(2730) \\
2670\end{array}$ & $-4.7 \pm 0.2$ & Tridacna sp. & $\begin{array}{l}\text { Unit } 3 ; 150-160 \mathrm{~cm} \text {, } \\
\text { Layer } 5\end{array}$ \\
\hline OZG341 & $2450 \pm 40$ & $\begin{array}{l}2730\left(2480^{*}\right) \\
\quad 2350\end{array}$ & -29.4 & Charcoal & $\begin{array}{l}\text { Unit 3: } 150-160 \mathrm{~cm} \text {, } \\
\text { Layer } 5\end{array}$ \\
\hline ANU-11767 & $2730 \pm 60$ & $\begin{array}{l}2680(2400) \\
2300\end{array}$ & $0.0 \pm 2.0 \mathrm{E}$ & Trochus sp. & $\begin{array}{l}\text { Unit 1: } 150-160 \mathrm{~cm} \text {, } \\
\text { Layer } 5\end{array}$ \\
\hline ANU-11931 ${ }^{\dagger}$ & $2330 \pm 180$ & $\begin{array}{l}2780(2350) \\
1900\end{array}$ & $-24.0 \pm 2.0 \mathrm{E}$ & Pot residue & $\begin{array}{l}\text { Unit 1: } 150-160 \mathrm{~cm} \text {, } \\
\text { Layer } 5\end{array}$ \\
\hline $\mathrm{OZG} 274^{\dagger}$ & $2580 \pm 40$ & $\begin{array}{l}2770(2740) \\
\quad 2510\end{array}$ & -14.2 & Pot residue & $\begin{array}{l}\text { Unit 1: } 150-160 \mathrm{~cm} \text {, } \\
\text { Layer } 5\end{array}$ \\
\hline ANU-11910 & $2450 \pm 200$ & $\begin{array}{l}2950\left(2480^{*}\right) \\
2000\end{array}$ & $-24.0 \pm 2.0 \mathrm{E}$ & Pot residue & $\begin{array}{l}\text { Unit 1: } 150-160 \mathrm{~cm} \text {, } \\
\text { Layer } 5\end{array}$ \\
\hline ANU-11934 & $3100 \pm 60$ & $\begin{array}{l}3020(2860) \\
2740\end{array}$ & $0.0 \pm 2.0 \mathrm{E}$ & Tridacna sp. & $\begin{array}{l}\text { Unit 3: } 210-220 \mathrm{~cm} \text {, } \\
\text { Layer } 5\end{array}$ \\
\hline ANU-11766 & $3200 \pm 50$ & $\begin{array}{l}3150(2990) \\
2850\end{array}$ & $2.3 \pm 0.2$ & Lambis sp. & $\begin{array}{l}\text { Unit 3: } 210-220 \mathrm{~cm} \text {, } \\
\text { Layer } 5\end{array}$ \\
\hline
\end{tabular}

$\dagger=$ AMS result. ${ }^{*}=$ Multiple calibration curve intercepts. $\mathrm{E}={ }^{13} \mathrm{C}$ estimated.

For discussion of rejected AMS dates see Clark (2004). 
11910) are limited by their large standard errors. The two ANSTO AMS dates (OZG-274, OZG-341) on charcoal and a pot residue have a narrower age span of 2750-2350 cal. B.p., which match marine shell ages and are considered to be more reliable age estimates.

Overall, the calibrated marine shell and charcoal/pot residue results provide a broadly comparable series of age ranges for upper and lower sections of the Ulong deposit. There is little indication for a substantial local reservoir age offset $(\Delta R)$ in the results, although the magnitude of $\Delta \mathrm{R}$ in Palau, as in other parts of Micronesia has yet to be determined (Southern et al. 2002). A date on charcoal with a range of 2150-1300 cal. B.P. (ANU-11930) does not, however, overlap with a marine shell result of $2740-2350 \mathrm{cal}$. B.P. (ANU-12107). Both are from the $70-80 \mathrm{~cm}$ spit, but dating samples were from different units.

It appears that during the period ca. 3000-2400 cal. B.P. natural beach sediments were rapidly accruing with the cultural deposit from $150-160 \mathrm{~cm}$ to $70-$ $80 \mathrm{~cm}$ dated to $2800-2500 \mathrm{cal}$. B.P. Sediment production is more likely to be caused by sea-level fall than by tectonic uplift, as Dickinson (2004:1021) records net Holocene subsidence of $0.6 \mathrm{~mm} /$ year for Palau. The rate of sea-level fall must, therefore, have outstripped island subsidence around 3000-2500 years ago. Such an interpretation suggests that half of the Ulong sequence is absent, and requires an explanation for the substantial occupation hiatus. The presence of a single AMS date (70-80 cm, ANU-11930) on charcoal with a span of 2150$1300 \mathrm{cal}$. B.P. might indicate that the sequence contains cultural material dating to after 2500 B.P. Some support for this has been found in new excavations at the site where an AMS date on residue from a buried pot (typical of middle ceramics; see below) has an age range of 2350-2130 cal. B.P. (Duncan Wright, ANU, pers. comm.). Since the vessel was found at the transition between Layers 4 and 5 at $110 \mathrm{~cm}$ depth, with related ceramics above it to $60-70 \mathrm{~cm}$ depth, a tentative conclusion is that the sequence extends to 2000-1000 B.P., but to an unknown extent. The reason for the disjunction between the majority of radiocarbon ages and the Ulong ceramic sequence is still uncertain, and can be examined by comparing the attributes of the thin blackware ceramics dating to 2400-1700 cal. B.P. recovered by IARII, which have yet to be reported in detail.

\section{CERAMIC ANALYSIS}

The Ulong ceramic assemblage comprised 6584 sherds weighing $76.3 \mathrm{~kg}$. Sherds from the top $0-50 \mathrm{~cm}$ of TP. 1 were used to sample the ceramics associated with the late prehistoric traditional village occupation in contrast to levels below $50 \mathrm{~cm}$ depth, where complete pottery samples from all excavation units (TP.1, Unit 1, Unit 3) were analyzed. The aim was to describe the pottery (sherd number/ weight) for each excavation unit and record rim and body sherd attributes to construct a ceramic sequence. This was done by illustrating lip and rim forms and recording metric variables identified in previous studies (rim orientation angle, exterior rim diameter, rim thickness and body sherd thickness; see Best 1984; Clark 1999; Desilets et al. 1999). Thirteen sherds were examined in petrographic thin section by William Dickinson (Arizona University); he identified four ceramic temper groups. A sample of 1000 body and rim sherds were sectioned with 
Table 2. Distribution and Weight of Excavated Body Sherds and Mean Sherd Thickness

\begin{tabular}{|c|c|c|c|c|c|c|c|}
\hline \multirow[b]{2}{*}{$\begin{array}{l}\text { EXCAVATION } \\
\text { DEPTH (CM) }\end{array}$} & \multicolumn{2}{|c|}{ TP.1 } & \multicolumn{2}{|c|}{ UNIT 1} & \multicolumn{2}{|c|}{ UNIT 3} & \multirow[b]{2}{*}{$\begin{array}{c}\text { SHERD } \\
\text { THICKNESS (MM) }\end{array}$} \\
\hline & NUMBER & $\begin{array}{l}\text { WEIGHT } \\
\text { (KG) }\end{array}$ & NUMBER & $\begin{array}{l}\text { WEIGHT } \\
(\mathrm{KG})\end{array}$ & NUMBER & $\begin{array}{l}\text { WEIGHT } \\
\text { (KG) }\end{array}$ & \\
\hline $0-10$ & 165 & 1.3 & & & & & \\
\hline $10-20$ & 374 & 5.9 & & & & & $8.52 \pm 2.14$ \\
\hline $20-30$ & 158 & 3.1 & & & & & \\
\hline $30-40$ & 148 & 3.0 & & & & & $8.30 \pm 2.01$ \\
\hline $40-50$ & 97 & 1.8 & & & & & \\
\hline $50-60$ & 172 & 1.9 & 396 & 7.1 & 196 & 3.1 & $9.24 \pm 2.32$ \\
\hline $60-70$ & 209 & 2.4 & 229 & 3.4 & 132 & 1.6 & \\
\hline $70-80$ & 330 & 2.9 & 207 & 2.6 & 235 & 2.3 & $7.73 \pm 2.12$ \\
\hline $80-90$ & 118 & 1.0 & 76 & 1.0 & 306 & 2.5 & \\
\hline $90-100$ & 102 & 0.7 & 108 & 1.3 & 308 & 2.5 & $7.54 \pm 2.12$ \\
\hline $100-110$ & 90 & 0.8 & 33 & 0.3 & 239 & 2.5 & \\
\hline $110-120$ & 59 & 0.5 & 50 & 0.3 & 186 & 1.8 & $7.84 \pm 2.79$ \\
\hline $120-130$ & 47 & 0.4 & 109 & 1.1 & 143 & 1.5 & \\
\hline $130-140$ & 5 & $<0.1$ & 102 & 1.1 & 34 & 0.3 & $7.34 \pm 2.64$ \\
\hline $140-150$ & 0 & 0 & 43 & 0.4 & 74 & 0.7 & \\
\hline $150-160$ & 42 & 0.3 & 262 & 2.7 & 29 & 0.1 & $7.38 \pm 2.47$ \\
\hline $160-170$ & 36 & 0.4 & 209 & 1.7 & 27 & 0.1 & \\
\hline $170-180$ & 65 & 0.3 & 136 & 0.9 & 0 & 0 & $6.81 \pm 2.29$ \\
\hline $180-190$ & 11 & 0.1 & 105 & 0.8 & 9 & $<0.1$ & \\
\hline $190-200$ & 12 & $<0.1$ & 201 & 1.0 & 9 & $<0.1$ & $5.78 \pm 1.47$ \\
\hline $200-210$ & & & 7 & 0.1 & 94 & 1.3 & \\
\hline $210-220$ & & & 50 & 0.2 & 24 & 0.3 & na \\
\hline Total & 2240 & 26.8 & 2323 & 25.9 & 2021 & 20.3 & \\
\hline
\end{tabular}

Note: TP.1 sample for $0-50 \mathrm{~cm}$ depth. Sherds from $200-240 \mathrm{~cm}$ were not measured due to light surface erosion.

a gem saw and plane surfaces were examined under low-power magnification to identify temper grains. Calcareous inclusions were tested with 10 percent $\mathrm{HCl}$.

The weight and number of body sherds in each excavation unit is shown in Table 2. The sherd distributions display similar trends with sherd numbers peaking in Layer 1 (TP.1) and at the base of Layer $2(70-90 \mathrm{~cm})$. In all units sherd quantities then decline steadily with the fewest sherds recorded from the 130$140 \mathrm{~cm}$ level. Below this point sherd numbers display a slight but consistent increase in Layer 5, and were infrequent below $190 \mathrm{~cm}$ depth. Sherd abundance varies along the transect, particularly in Layer 5 , where sherds were more frequent in Unit 1 than in Unit 3 and TP.1.

\section{Body Sherd Thickness}

Body sherd thickness (mm) was measured on a sample of 2254 sherds with digital callipers. The minimum sample size for each $10 \mathrm{~cm}$ spit was 100 sherds, and all sherds in an opened bag were measured to remove a potential selection bias toward thick or thin sherds. The three lowest levels $(170-180 \mathrm{~cm}, 180-190 \mathrm{~cm}$, $190-200 \mathrm{~cm}$ ) had less than 100 sherds (range $=65-87$ ) and $20-\mathrm{cm}$ intervals were 
used to increase sample numbers. Table 2 shows the mean body sherd thickness for sherd samples by $20-\mathrm{cm}$ interval. The lowest mean sherd thickness occurs at the base of the deposit $(180-200 \mathrm{~cm}$, mean $=5.8 \mathrm{~mm})$ with the greatest sherd thickness in ceramics associated with the traditional village occupation (40-60 $\mathrm{cm}$, mean $=9.2 \mathrm{~mm}$ ). The decrease in mean sherd thickness in the upper levels of Layer $1(0-20 \mathrm{~cm}$, mean $=8.3 \mathrm{~mm})$ was due to the presence of thick and thin-walled flange rim vessels (see below).

Osborne (1966:64) was the first to note that assemblages with "thin" ( $\leq 6 \mathrm{~mm})$ or "extra thin" $(<3.5 \mathrm{~mm})$ sherds were early in the Palauan sequence, and Welch (2002:164-165) has recently reported pottery from Ngerlumud Hill dominated by "very thin" (2-7 mm thick) sherds, which might date to the early first millennium C.E. (see also Lucking 1984:153-154). However, the acidic soils of Babeldaob can cause erosion and exfoliation of sherd surfaces, especially in the case of the oldest ceramics, which have been interred the longest (Desilets et al. 1999:229).

It has been unclear if the oldest Palauan pottery, therefore, actually had thin walls or whether wall thickness was influenced by post-depositional erosion. In the Ulong sequence body thickness does increase through time but probably not as significantly as the data suggests (Table 2). Sherds from the lowest spits had evidence of minor-to-moderate erosion from the degree of edge rounding, the presence of surface pitting, and delaminated sherds. These traits are consistent with some intertidal reworking of the basal ceramic deposit, and sherds that had been protected by their proximity to fragments of shell or coral did not display such features. Moderately eroded potsherds were not measured, but ceramics that had received enough minor abrasion to account for the removal of perhaps 1-2 $\mathrm{mm}$ of sherd thickness could have been sampled. If so, then the major temporal pattern might best be illustrated by comparing the better-preserved Layer 5 sherds $(150-160 \mathrm{~cm}, 7.6 \pm 2.4 \mathrm{~mm})$ with those from the base of Layer $2(70-80 \mathrm{~cm}$, $7.2 \pm 1.9 \mathrm{~mm})$ and top of Layer $2(40-50 \mathrm{~cm}, 9.3 \pm 2.4 \mathrm{~mm})$. This suggests that the assemblage with the thinnest vessel walls is in lower Layer 2 and Layer 3 (see below) rather than Layer 5, and while the difference is slight in terms of average sherd thickness, the smaller standard deviation of the Layer 2 assemblage suggests it is the most coherent "thin-walled" assemblage in the Ulong sequence. Whether this assemblage is stylistically distinct from or similar to the thin blackwares on Babeldaob (Welch 2001) will help to refine the age of the middle ceramics.

\section{Vessel Attributes}

Rim profiles are shown in Figure 4 to illustrate the ceramic variation in the Ulong sequence. Three stylistic groups correspond approximately with pottery from an upper $(0-60 \mathrm{~cm})$, middle $(60-120 \mathrm{~cm})$, and basal $(120-200 \mathrm{~cm})$ ceramic assemblage. Figure 5 has rim variables and preliminary reconstructions of the main vessel forms in each assemblage. The threefold division of ceramics to upper, middle, and basal assemblages provides a framework to examine stratigraphic variation in other cultural remains, including marine shellfish and other fauna. Uncertainty about the precise age of cultural materials from the middle of the sequence (2000-1000 B.P.) in the radiocarbon results (discussed above) makes it preferable to divide the sequence based on the coherent and demonstrable ceramic groups. 


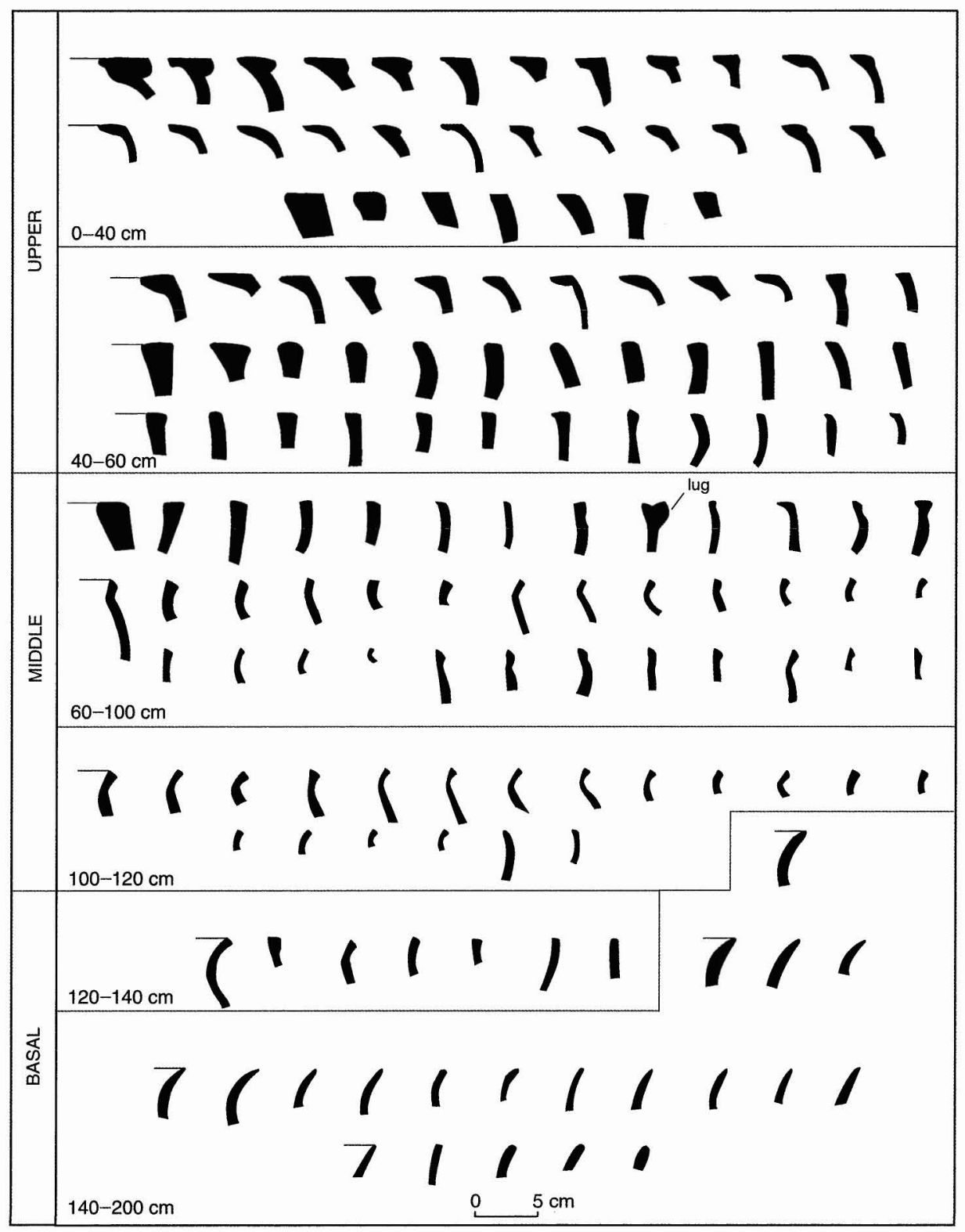

Fig. 4. Rim profiles (right-hand profiles) of ceramics excavated from Ulong Island.

Upper Ceramics: $0-60 \mathrm{~cm}$-The main vessel form in Layer $1(0-40 \mathrm{~cm})$ was a grog-tempered bowl with an inverted flange rim and a large orifice (Figure 4 and 5). Decoration consisted of incised chevrons below the rim of a flanged-rim vessel and fingernail impressing at the same location on another rim. Paste color consisted of a dark black core that extended to the vessel surface or which was flanked by thin orange-red surfaces. Immediately below Layer $1(0-40 \mathrm{~cm})$ flange rims were less frequent and a thick-walled bowl with minor rim inversion was the 


\begin{tabular}{|c|c|c|c|c|}
\hline Depth & Diameter & Rim orientation & Rim thickness & Vessel form \\
\hline $0-40 \mathrm{~cm}$ & $\begin{array}{c}36 \mathrm{~cm} \\
\mathrm{n}=16\end{array}$ & $\begin{array}{l}-70^{0} \\
n=35\end{array}$ & $\begin{array}{c}7.9 \mathrm{~mm} \\
\mathrm{n}=21\end{array}$ & \\
\hline $40-60 \mathrm{~cm}$ & $\begin{array}{c}36 \mathrm{~cm} \\
\mathrm{n}=14\end{array}$ & $\begin{array}{l}-16^{0} \\
n=33\end{array}$ & $\begin{array}{c}11.3 \mathrm{~mm} \\
\mathrm{n}=21\end{array}$ & \\
\hline $60-120 \mathrm{~cm}$ & $\begin{array}{c}32 \mathrm{~cm} \\
\mathrm{n}=10\end{array}$ & $\begin{array}{l}-2^{0} \\
n=20\end{array}$ & $\begin{array}{c}7.3 \mathrm{~mm} \\
\mathrm{n}=12\end{array}$ & \\
\hline $60-120 \mathrm{~cm}$ & $\begin{array}{c}27 \mathrm{~cm} \\
\mathrm{n}=20\end{array}$ & $\begin{array}{c}28^{0} \\
n=36\end{array}$ & $\begin{array}{c}6.3 \mathrm{~mm} \\
\mathrm{n}=23\end{array}$ & \\
\hline $140-200 \mathrm{~cm}$ & $\begin{array}{l}26 \mathrm{~cm} \\
\mathrm{n}=14\end{array}$ & $\begin{array}{c}35^{0} \\
n=20\end{array}$ & $\begin{array}{c}7.1 \mathrm{~mm} \\
\mathrm{n}=15\end{array}$ & \\
\hline
\end{tabular}

Fig. 5. Ulong metric rim variables (mean) and reconstructed vessel forms. Reconstructed vessel forms were based on extrapolations of the largest rim fragments from each assemblage and do not represent the full range of vessel variability.

dominant form (Figure 4 and 5). Lip shapes were flat or rounded with parallel or gradually thickening or thinning rim profiles. One sherd was from a carinated bowl, and decoration was limited to two red painted sherds and fingernail impression on the exterior of a small bowl with a pointed lip and on the surface of a flat lip. Paste and temper were similar to that of flange-rim vessels. Sherd cross sections and fracture patterns were consistent with construction by coiling and paddle-anvil compression, with large flange rims made separately and attached to the vessel body.

Middle Ceramics: $60-120 \mathrm{~cm}$-Vessel rims from Layer 2 and 3 came from a relatively thin-walled vessel with an everted rim, flat lip, and parallel rim profile. In some instances the clay below the lip had been compressed to create a small collar rim. Vessel form varied from a subglobular jar with a short rim to a deep ovoid jar with vertical walls, a pointed lip, and a small collar rim. The mean orifice diameter of $27 \mathrm{~cm}$ is much smaller than that of Layer 1 vessels. Incurving bowls with slightly thicker rims and larger orifice diameter were also present, but it is unclear if the form gave rise to the thick-walled bowls found in Layer $2(40-60 \mathrm{~cm})$. Rim-lip combinations were highly variable, with incurving lips, external circumference grooving, and very small everted rims from vessels with orifice diameters less than $15 \mathrm{~cm}$. A bowl rim had a handle or lug beneath the lip. The only decoration was a red-painted bowl sherd that was also perforated below the rim. Sectioned sherds had a black or gray-black core flanked by orange, gray, or red layers indicating that the clay had a high organic content. The method of vessel construction could not be inferred from the smooth body surfaces and well-fired paste of the thin-walled assemblage.

Basal Ceramics: $120-200 \mathrm{~cm}$-Rims from Layers 4 and 5 were from moderately everted jars with a gradual rim-body contour and a mean orifice diameter of 26 


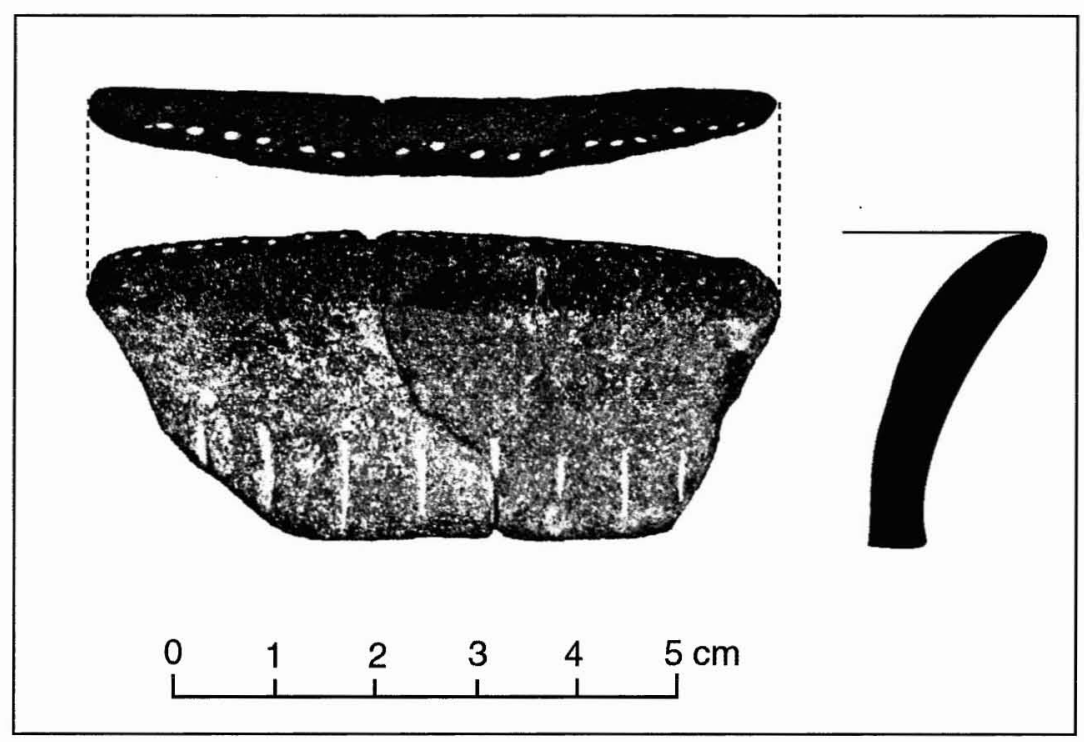

Fig. 6. Rim sherd from basal ceramic assemblage (Unit 1: 180-190 cm) decorated with linear incision (shoulder) and punctate (lip), possibly lime infilled.

$\mathrm{cm}$. Only two rims might belong to bowls with a vertical rim orientation. Lips from the lowest levels $(160-200 \mathrm{~cm})$ included rounded as well as pointed forms. A decorated rim sherd was red slipped and burnished, but light abrasion has likely removed the slip layer from many other sherds as 7 percent of rim sherds had traces of red slip. Linear incision was recorded on an interior rim and on exterior rim shoulders, and one rim had a fingernail impression on the lip. Several sherds had converging incised lines infilled with lime or naturally precipitated calcium carbonate. A rim had a series of small punctate markings along the lip made with a multiple or single-toothed tool and linear incising on the shoulder (Figure 6), and two probable neck sherds displayed uneven modeled grooves. Sherd fracture patterns show that rim sections, and probably the vessel body, were constructed by coiling followed by paddle and anvil compression.

\section{Temper Groups}

Dickinson identified five temper groups in the sample of 13 sherds examined in thin section: grog (Group 1), grog + terrigenous (Group 2), calcareous + placer/ nonplacer terrigenous (Group 3 and 4), and volcanic (Group 5). Those with terrigenous grains are of andesitic character and indicate ceramic transfer from the bedrock islands of central Palau. Compared with other Palauan ceramics, which are dominated by grog tempers (Fitzpatrick et al. 2003), most of the Ulong sherds had terrigenous and calcareous grains exclusive of grog (Groups 3-5). In the initial sample examined in thin section by Dickinson, the calcareous-terrigenous tempered sherds were found only in Layers 4 and 5, while sherds with grog temper occurred in levels above $100 \mathrm{~cm}$ depth.

The stratigraphic distribution of the temper groups was examined further in a 


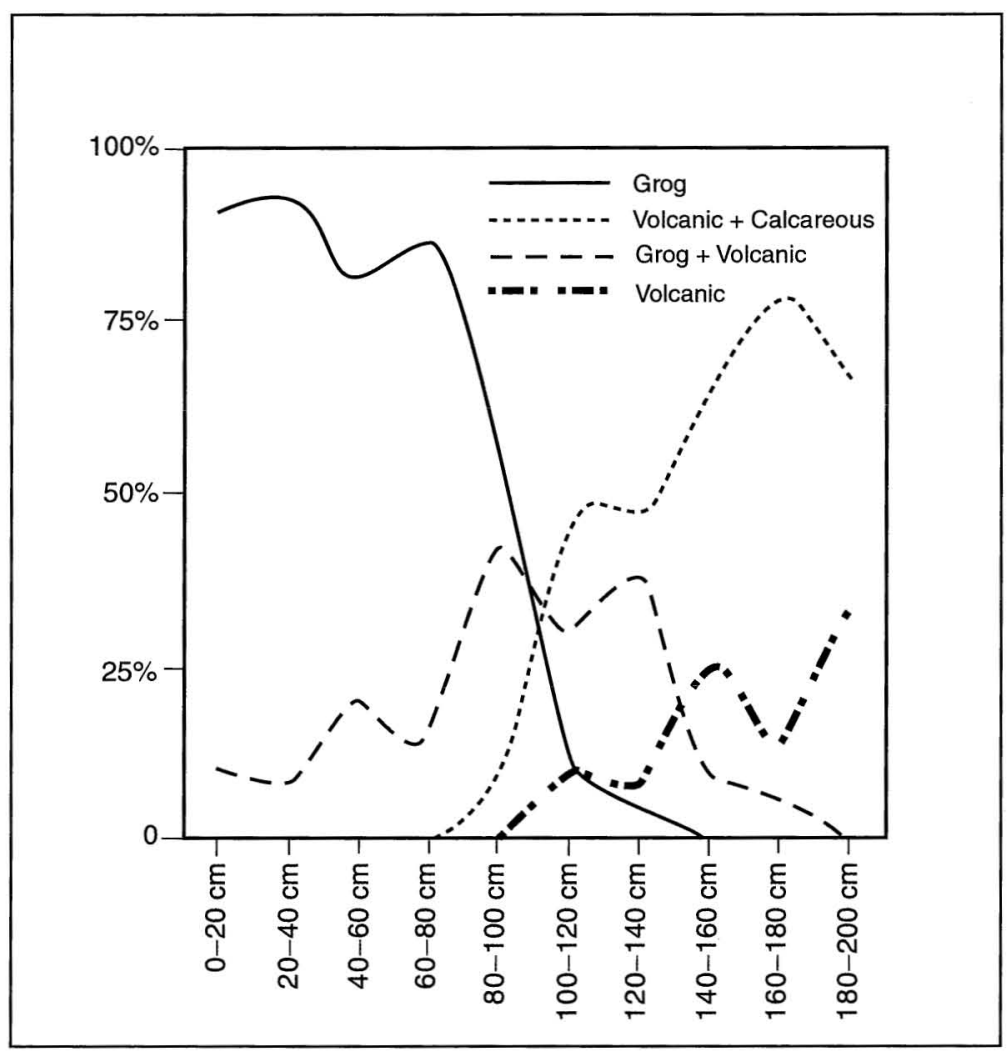

Fig. 7. Percentage of four temper groups by depth in Ulong Island excavations (see text for sample details and method).

sample of 1000 sectioned sherds under low-power magnification. The sample size was 100 sherds for each $20 \mathrm{~cm}$ level. Temper groups were those identified in Dickinson's study except that calcareous + placer/nonplacer terrigenous groups were combined. In sectioned sherds volcanic and calcareous grains were clearly visible, but fine particles of grog in sherd pastes were difficult to positively identify, and it is possible that some sherds from Layer 1 did not include a manually added temper, and some identified as having an exclusive volcanic temper also included finely ground grog.

The main stratigraphic distinction was between sherds containing grog and those containing calcareous grains (Figure 7). The rapid increase in grog and concomitant decline in calcareous-terrigenous temper at $100-120 \mathrm{~cm}$ is probably even more abrupt as some deposit intermixing has taken place. However, there are reasonable numbers of sherds with the composite grog-terrigenous temper at $120-140 \mathrm{~cm}$ that may represent a transitional temper type. Sherds with only volcanic grains are most abundant in the lowest levels $(140-200 \mathrm{~cm})$, and this might reflect a preference by potters for volcanic sand or, alternatively, a greater durability of sand-tempered sherds compared with calcareous-tempered ceramics in the reworked lower levels. Although volcanic grains were always associated 
with calcareous grains in Layer 5, the temper of several sherds was almost completely calcareous. The timing of the transition from calcareous-terrigenous to grog tempers is difficult to estimate, but grog was probably an established clay additive in Palau by 2400 cal. B.P.

Overall, there are clear stylistic and compositional differences between each of the three ceramic assemblages. The basal pottery was made by coiling and has a form and temper not recorded previously in Palau (Desilets et al. 1999; Intoh 1996; Osborne 1979; Snyder 1989). The middle pottery vessels were small-tomedium thin-walled jars with short outcurving rims tempered with grog. Upper ceramics were grog-tempered bowls with direct and flange rims, a large orifice diameter, and thick body walls.

\section{NONCERAMIC ARTIFACTS}

There were 14 worked artifacts consisting of five stone tools, three pieces of striated ironstone, three tuff abraders, and three shell artifacts. Other items were manuports of ironstone and andesite, a few small chert flakes, and a section of stingray spine. The majority of artifacts were recovered from TP.1 and Unit 3 between 80 and $120 \mathrm{~cm}$ depth, and the stone tools were brought from nearby Babeldaob.

\section{Adzes}

Five stone tools were made in an andesitic-basaltic volcanic breccia common on Babeldaob (Corwin et al. 1956). Two were from large adzes with oval and plano-convex cross sections (Figure 8: $A, C$ ), while the two from lower levels belonged to small adzes with oval-rectangular cross sections (Figure 8: $B, D$ ). An unusual tool was a small stone adze with an asymmetric triangular cross section that was presumably side-hafted or mounted as a chisel (Figure 8: E).

Major and minor element analysis using X-ray fluorescence for the two large adze fragments (Figure 8: $A, C$ ) was made at the Australian National University and the results were compared to nine artifacts surface collected from Oikull (southern Babeldaob) and Angaur Island and a sample of fine-grained basalt from the hill slope above Oikull. Cores or sawn slices of $0.7-1.0 \mathrm{~g}$ were milled to a fine powder in a tungsten carbide ring mill and fused with lithium borate flux to make homogeneous glass discs $(0.27 \mathrm{~g}$ sample fused with $1.72 \mathrm{~g}$ flux to make a disc $30 \mathrm{~mm}$ diameter and $1 \mathrm{~mm}$ thick). Disk composition was analyzed with a Philips PW2400 X-ray fluorescence spectrometer with a $\mathrm{Rh}$ tube operating at $2.4 \mathrm{~kW}$. The method was calibrated against a suite of 28 standard rocks for $\mathrm{Na}$, $\mathrm{Mg}, \mathrm{Al}, \mathrm{Si}, \mathrm{P}, \mathrm{S}, \mathrm{K}, \mathrm{Ca}, \mathrm{Ti}, \mathrm{Mn}$, and Fe. Loss of ignition values of 3-7 percent were due to vaporization of volatiles $\left(\mathrm{H}_{2} \mathrm{O}\right.$ and $\left.\mathrm{CO}_{2}\right)$ in addition to rock weathering (Andrew Christy, Geology Department, ANU, pers. comm.). Detection limits were single ppm for most elements and somewhat higher for $\mathrm{Na}$ and $\mathrm{Si}$.

Results were compatible with a Palauan origin for the adzes (Appendix 1), and a multidimensional scaling (MDS) analysis of the trace element data was carried out using SPSS 11.0 with the simple aim of investigating variability among samples. All trace elements were included first, and the results were compared to a second analysis of 12 trace elements ( $\mathrm{Sc}, \mathrm{V}, \mathrm{Cr}, \mathrm{Ni}, \mathrm{Cu}, \mathrm{Zn}, \mathrm{Rb}, \mathrm{Sr}, \mathrm{Y}, \mathrm{Zr}, \mathrm{Nb}$, 


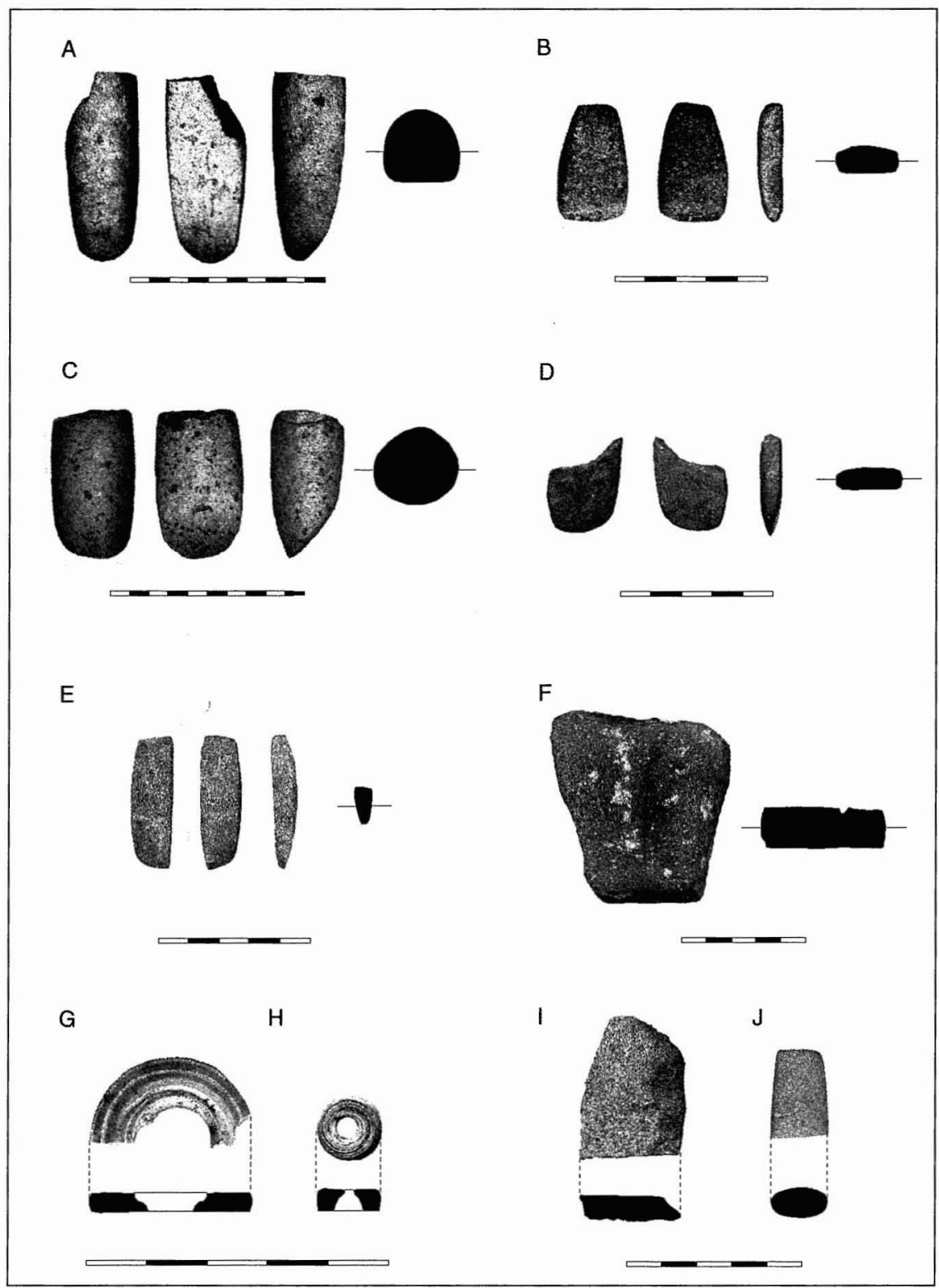

Fig. 8. Artifacts from Ulong Island excavations (scales in $\mathrm{cm}$ ). $A-E$ : stone tools $(A=$ PL-02, $B=$ PL-01); $F$ : worked ironstone; $G-H$ : worked shell; $I-J$ : tuff abraders.

$\mathrm{Ba}$ ) used in discriminating Polynesian basalts, providing almost identical results. Considerable variation in the stone sources is suggested with the Ulong samples (PL-01, PL-02) somewhat similar to artifacts from Oikull and Angaur, but unlike the Oikull basalt source (Figure 9, PL-12). A comprehensive sampling program including analyses of potential stone sources and artifacts is clearly needed in Palau to more accurately investigate sample variation. 


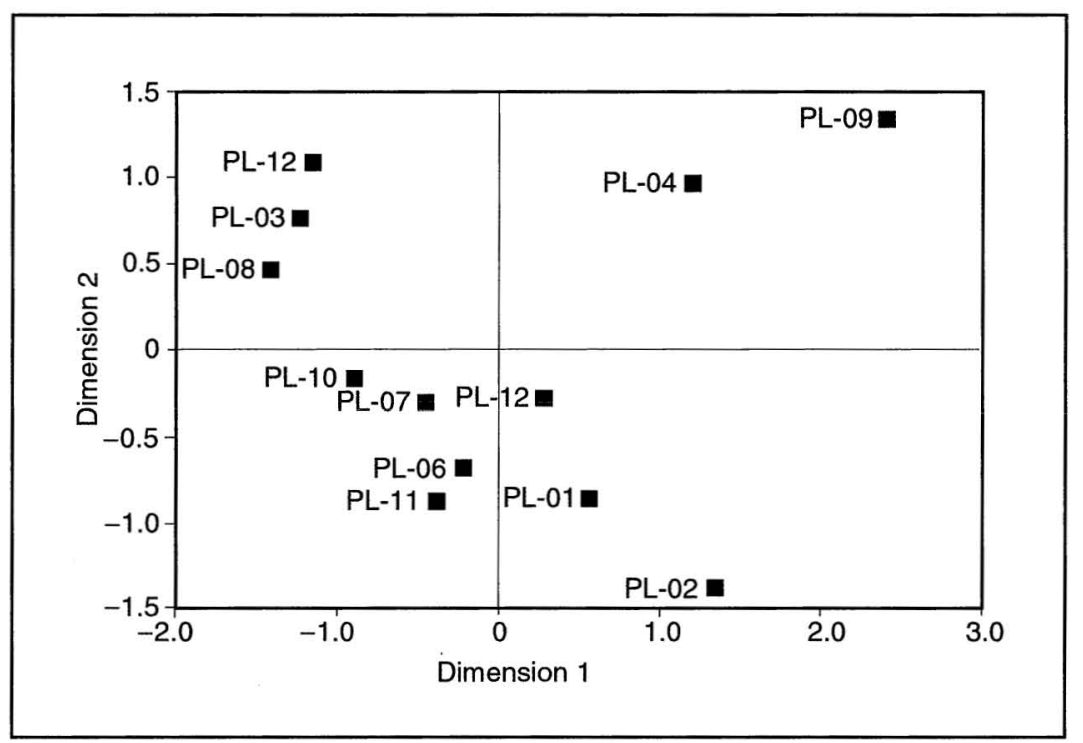

Fig. 9. Multidimensional scaling analysis of XRF results from Palauan stone tools using 12 trace elements ( $\mathrm{Sc}, \mathrm{V}, \mathrm{Cr}, \mathrm{Ni}, \mathrm{Cu}, \mathrm{Zn}, \mathrm{Rb}, \mathrm{Sr}, \mathrm{Y}, \mathrm{Zr}, \mathrm{Nb}, \mathrm{Ba})$ : Ulong (PL-01, PL-02), Angaur Island (PL-03, PL-04, PL-05), and Oikull (PL-07, PL-08, PL-09, PL-10, PL-11). PL-12 is a sample of andesitic basalt outcropping above the traditional village at Oikull.

\section{Worked Ironstone and Tuffs}

Two pieces of ironstone, one from $80-90 \mathrm{~cm}$ (Unit 3 and TP.1) and one from 110-120 cm (TP.1), had striated and grooved surfaces to obtain iron-rich powder probably used to make red paint. A small piece of ironstone had opposing drill holes that had not penetrated completely through, and all four surfaces had been abraded. The surface of a large piece of ironstone suggested that it was placed on a flat surface and worked with a small tool with an asymmetric triangular cross section (Figure 8: F). The composition of the ironstone was analyzed with a JEOL JSM6400 SEM equipped with a Link Analytical PCXA energy dispersive spectrometer (Australian National University). The main constituents were oxides of iron, aluminium, and silica (Appendix 1). Coarse and fine-grained volcanic tuffs were used as abraders. Two had parallel plane surfaces (Unit 3; 100-110 cm [Figure 8: I] and TP.1: $160-170 \mathrm{~cm})$, and a fine-grained abrader had an oval cross section (TP.1: 70-80 cm, Figure 8: J).

\section{Shell Artifacts}

Shell artifacts were surprisingly less abundant than stone tools, with only three pieces of worked shell, all from the $100-110 \mathrm{~cm}$ level. They were a thin Conus sp. disk (diameter $=27 \mathrm{~mm}$, thickness $=2.8 \mathrm{~mm}$, weight $=1.4 \mathrm{~g}$ ), a small bead of Terebra sp. (diameter $=10 \mathrm{~mm}$, thickness $=3.7 \mathrm{~mm}$, weight $=0.3 \mathrm{~g}$ [Figure 8: G, H]). A drilled and ground piece of Tridacna sp. (weight $=8.6 \mathrm{~g}$ ) might be from an ornament. Keate $(2000: 375)$ illustrates a hafted stingray spine "dagger" 
Table 3. Marine Shellfish from tP.1 By Weight and Assemblage

\begin{tabular}{|c|c|c|c|}
\hline SPECIES & $\begin{array}{c}\text { TP.1 UPPER } \\
(0-60 \mathrm{CM})\end{array}$ & $\begin{array}{l}\text { TP.1 MIDDLE } \\
(60-120 \mathrm{CM})\end{array}$ & $\begin{array}{l}\text { TP.1 BASAL } \\
(120-200 \mathrm{CM})\end{array}$ \\
\hline Tridacna sp. & 331.5 & 1154.6 & 6632.8 \\
\hline Hippopus hippopus & 75.1 & 1612.1 & 4344.9 \\
\hline Trochus niloticus & 42.4 & 167.4 & 1400.4 \\
\hline Lambis sp. & 27 & 413.2 & 1144.4 \\
\hline Lambis truncata & 0 & 0 & 1250.5 \\
\hline Atacodea striata & 3.6 & 72.0 & 132.7 \\
\hline Pitar sp. & 1.2 & 0 & 8.5 \\
\hline Trachycardium sp. & 4.2 & 28.5 & 13.3 \\
\hline Strombus sp. & 45.9 & 45.6 & 268.1 \\
\hline Periglypta sp. & 0 & 17.7 & 125.1 \\
\hline Terebra maculata & 0 & 0 & 118.9 \\
\hline Anadara sp. & 0 & 0 & 102.2 \\
\hline Spondylus sp. & 0 & 0 & 21.9 \\
\hline Cypraea sp. & 0 & 19.9 & 13.8 \\
\hline Geloina sp. & 0 & 39.2 & 7.8 \\
\hline Nerita plicata & 0 & 11.1 & 6.5 \\
\hline Turbo sp. & 18.7 & 0 & 4.7 \\
\hline Tellina palatum & 0 & 0 & 1.5 \\
\hline Arca ventricosa & 0 & 0 & 0.8 \\
\hline Terebralia sp. & 0 & 0 & 0.7 \\
\hline Chlamys sp. & 1.1 & 0 & 0 \\
\hline Fragum unedo & 10.5 & 0 & 0 \\
\hline Pythia sp. & 0.4 & 0 & 0 \\
\hline Fimbria sp. & 0 & 10.8 & 0 \\
\hline Unidentified & 30.4 & 151.9 & 385.3 \\
\hline Total (g) & 593 & 3744 & 15,985 \\
\hline
\end{tabular}

Note: Pythia sp. is a common land snail.

collected from Palau in 1783 (see also Kirch and Yen 1982:270), and a section of stingray spine $(50-60 \mathrm{~cm})$ could be an artifact.

\section{FAUNAL REMAINS}

\section{Shellfish}

The TP.1 shellfish assemblage was analyzed with a Palau shell reference collection identified by c. Szabo (ANU). The TP.1 collection was examined because several bags of shell midden from Unit 1 and 3 had broken in transit, compromising quantification of the complete shellfish collection. The stratigraphic trends in shellfish observed in TP.1 were, however, consistent with those observed during sorting of the Unit 1 and 3 shellfish. There was $20.3 \mathrm{~kg}$ of shellfish in TP.1, with most from 120-200 cm. Preservation was poor in the $0-60 \mathrm{~cm}$ level, with significant erosion of shell surfaces from humic acids, but was excellent in underlying beach sands. There was an increasing amount of complete and partially complete remains of large shellfish below $120 \mathrm{~cm}$ depth (Table 3).

Although there was considerable variation in the shellfish, by weight a few taxa make up the majority (Table 3). Species diversity and abundance was low in the 
0-60 cm upper deposit with small amounts of Tridacna sp., Hippopus hippopus, Strombus sp., and Trochus sp. From 60-120 cm species diversity increased, as did the quantity of Tridacna sp. and Hippopus hippopus remains. In the basal deposit $(120-200 \mathrm{~cm})$ large individuals of Tridacna sp., Hippopus hippopus, Trochus niloticus, and Lambis sp. were common. The four species constitute 85 percent of the assemblage by weight and no other species accounts for more than 2 percent of the assemblage. The species indicate collection from the exposed reef edge and soft and hard intertidal/subtidal substrates. The intertidal zone at Ulong never appears to have suited gregarious and easily accessible sediment-dwelling species like the bivalves Anadara antiquata and Gafrarium tumidum. Instead, the first occupants collected large individuals of high meat-yielding species.

\section{Fish}

The fish bone assemblage from Ulong weighed $3.6 \mathrm{~kg}$ with a NISP of 4963 and an MNI of 156. Identifications were made with the ANU fish reference collection, which is primarily focused on five head bones (dentary, maxilla, premaxilla, articular, quadrate), although it includes small collections of other elements such as vertebra, scutes, spines, and scales.

Identified bones were mainly of inshore tropical reef fish species. Bone abundance in the $0-60 \mathrm{~cm}$ deposit is greater than shown in Table 4 as the faunal

Table 4. Identified Bone from Ulong Excavations

\begin{tabular}{|c|c|c|c|c|c|c|c|c|c|}
\hline & \multicolumn{3}{|c|}{ UPPER (0-60 CM) } & \multicolumn{3}{|c|}{ MIDDLE $(60-120 \mathrm{CM})$} & \multicolumn{3}{|c|}{ BASAL $(120-200 \mathrm{CM})$} \\
\hline & NISP & MNI & $\begin{array}{l}\text { WEIGHT } \\
\text { (G) }\end{array}$ & NISP & MNI & $\begin{array}{l}\text { WEIGHT } \\
\text { (G) }\end{array}$ & NISP & MNI & $\begin{array}{l}\text { WEIGHT } \\
\text { (G) }\end{array}$ \\
\hline \multicolumn{10}{|l|}{ Fish family } \\
\hline Muraenidae & 9 & 3 & 8 & 3 & 2 & 3 & 3 & 1 & 6 \\
\hline Serranidae & 27 & 8 & 20 & 25 & 7 & 32 & 11 & 3 & 7 \\
\hline Carangidae & & & & 1 & 1 & 1 & 1 & 1 & 1 \\
\hline Nemipteridae & 50 & 11 & 108 & 41 & 10 & 56 & 23 & 3 & 28 \\
\hline Lethrinidae & 10 & 4 & 9 & 9 & 2 & 5 & 6 & 3 & 9 \\
\hline Labridae & 14 & 3 & 25 & 9 & 8 & 17 & 2 & 1 & 1 \\
\hline Scaridae & 95 & 20 & 316 & 106 & 20 & 229 & 74 & 13 & 214 \\
\hline Acanthuridae & 5 & 1 & 3 & 11 & 1 & 4 & 5 & 1 & 2 \\
\hline Balistidae & 19 & 3 & 27 & 16 & 2 & 26 & 15 & 2 & 24 \\
\hline Diodontidae & 76 & 3 & 64 & 60 & 4 & 129 & 9 & 3 & 42 \\
\hline Elasmobranchii & 63 & 1 & 56 & 16 & 1 & 11 & 3 & 1 & 1 \\
\hline $\begin{array}{l}\text { Fish ?sp. } \\
\text { Turtle/bird/rat }\end{array}$ & 1439 & - & 941 & 1509 & - & 460 & 809 & - & 193 \\
\hline Turtle sp. & 16 & 1 & 36 & 169 & 1 & 309 & 67 & 1 & 65 \\
\hline Bird ?sp. & 2 & 1 & 1 & 16 & 1 & 2 & 2 & 1 & 1 \\
\hline Rat ?sp. & 6 & 2 & 1 & - & - & - & - & - & - \\
\hline Mammal ?sp. & 3 & - & 6 & 3 & 1 & 5 & 1 & - & 13 \\
\hline Unidentified & 38 & - & 14 & 4 & - & 5 & 62 & - & 87 \\
\hline Total & 1872 & 61 & 1635 & 1998 & 61 & 1294 & 1093 & 34 & 694 \\
\hline
\end{tabular}

Note: Faunal sample $50-200 \mathrm{~cm}$ is from all excavation units (TP.1, Unit 1, Unit 3) and $0-50 \mathrm{~cm}$ from TP.1 only. 
sample from the upper $50 \mathrm{~cm}$ was from TP.1 only. As a percentage of MNI the three most common families were parrotfish (Scaridae 35-42 percent), sea bream (Nemipteridae, Monotaxis granoculis), and rock cod (Serranidae). Other families were moray eels (Muraenidae), porcupinefish (Diodontidae), triggerfish (Balistidae), and wrasses (Labridae). Vertebrae from sharks/rays (Elasmobranchii) also occurred, with three teeth from the Oceanic white-tip shark (Carcharhinus longimanus) and a stingray spine. Netting, spearing, and poisoning were probably the major catching methods employed, while trolling for Scombridae, a family commonly found beyond the fringing reef today, was apparently rare. The prehistoric Ulong fish catch is similar to that identified from sites in southern Palau (Masse 1989), the west Pacific (Lapita), and early Neolithic sites from Island Southeast Asia (Rintaro 2003).

\section{Turtle/Mammal/Bird}

Turtle remains, represented by carapace and limb bone fragments, were most abundant at the base of the $60-120 \mathrm{~cm}$ deposit, where a small concentration occurred (Table 4). Bird bone was rare and identification to species could not be established because the articular ends of limb bones had been gnawn by rats, crabs, or humans. Rat bone from a species larger than the Pacific rat (Rattus exulans) was restricted to $0-60 \mathrm{~cm}$ and may belong to the Oriental house rat (Rattus tanezumi). Osborne (1979:66) recorded pig and goat bone from his earlier excavations, but several probable mammal bones could not be securely identified to either of these species, and may be dugong (Dugong dugon).

In summary, the Ulong faunal assemblage shows an expected reliance on inshore taxa of fish and shellfish. Fish bone was more frequent in the upper 0-60 $\mathrm{cm}$ of deposit, while shellfish remains are most abundant in the $120-200 \mathrm{~cm}$ deposit. This pattern suggests the targeting of local shellfish populations, particularly the large bivalves Tridacna and Hippopus and univalves Lambis and Trochus. This might also be suggested by the greater number of shellfish species in the basal deposit $(n=20)$ compared with middle and upper deposits $(n=12)$. The basal fish bone has almost certainly been reduced by intertidal activity, while humic acids, selection of large shells for tool use, and increased shell fragmentation from the late prehistoric occupation have likely reduced the amount of shell in the upper assemblage $(0-60 \mathrm{~cm})$.

\section{DISCUSSION AND CONCLUSION}

Recent work in Palau has extended our knowledge of its prehistory through detailed examination of previously known site types, particularly traditional villages and monumental earthworks, along with the discovery of new kinds of sites such as limestone burial caves, hilltop ring-ditch fortifications, and ridgeline sites (Fitzpatrick 2002, 2003; Reith and Liston 2001; Welch 2001; Wickler 2002). The deep and stratified Ulong site, as another example of the latter, contributes to current discussion about the age of colonization in Palau, where there is a substantial discrepancy between paleoenvironmental estimates for human arrival at ca. 4500-4300 cal. B.P. and archaeological data suggesting colonization at 3300-3000 cal. B.P. Whether a long or a short chronology is considered likely 
for Palau is important for the interpretation of the Ulong sequence, and the paleoenvironmental data is discussed further below.

An early human presence in Palau 4500-4300 cal. B.P. has been cautiously inferred from the analysis of four sediment cores taken from the main island of Babeldaob (Athens and Ward 1999, 2001; Welch 2001). Collectively, the cores show a decline in forest taxa and an increase in microscopic charcoal particles, Pandanus pollen, and four types of fern spores (Lycopodium cernum, Gleichenia linearis, Psilate monolete, Psilate trilete). In two cores from Ngerekebesang Island, vegetation disturbance is dated to $5750-5350$ cal. B.P., raising the possibility that human arrival on Palau occurred before the mid Holocene (Athens and Ward 2001 : 171).

In the Ngerchau core eight grains of giant swamp taro (Cyrtosperma chamissonis) occur in contexts indicating deposition 4500-4300 B.P., which Athens and Ward (2001:172) suggest "appears to be the 'smoking gun' establishing human agency at a very early time." However, disturbance indicators, such as charcoal particles, Pandanus, and fern spores (Lycopodium and Psilate), cited by Athens and Ward $(1999,2001)$ as evidence of prehistoric human activity, increase dramatically around $3000 \mathrm{cal}$. B.P. in both the Ngerchau and Yano cores (Athens and Ward 1999: Fig. 19; 2001).

The possibility that climatic change was responsible for forest decline and charcoal production at 4500 cal. B.P. in Palau was canvassed and rejected by Athens and Ward (1999:95-98; 2001). Recent work, though, indicates the onset of modern El Niño-Southern Oscillation (ENSO) periodicities began throughout the tropical Pacific about 5000 years ago, with higher precipitation variability leading to vegetation disturbance and increased charcoal production from natural fires (Gagen et-al. 2004). Sediment records from the west and east Pacific demonstrate that climatic changes were capable of affecting vegetation regimes in ways that could be interpreted as having a prehistoric human cause, including an increase in charcoal production and fluctuation in the composition of plant communities.

In New Guinea, where human occupation goes back at least 40,000 years, a mid Holocene increase in macro charcoal particles was interpreted by Haberle and Ledru (2001) as resulting from the onset of ENSO conditions, but an anthropogenic cause is also feasible given recent evidence for agriculture at $6500 \mathrm{cal}$. B.P. in the highlands (Denham et al. 2003). In recently occupied Remote Oceania (3000-700 cal. B.P.), charcoal particles occur in mid to late Holocene sediments of prehuman age in significant quantities on Alexander Selkirk Island (Juan Fernandez group), Norfolk Island, and New Caledonia (Haberle 2003; McPhail et al. 2001; Stevenson and Dodson 1995). In Fiji, a core from Bonita Bog had charcoal particles interpreted as evidence of anthropogenic burning at $4300 \mathrm{cal}$. B.P., but the major phase of vegetation change took place at $3000 \mathrm{cal}$. B.P. (Southern 1986:175, 186-187), similar to the Ngerchau core. There is currently no reliable archaeological evidence for settlement of Fiji earlier than ca. $2900 \mathrm{cal}$. B.P. (Clark and Anderson 2001), and if charcoal was deposited at 4300 B.P. then climatic change is the most likely cause.

It is premature, then, to rule out climatic events as the cause of vegetation change dating to the mid Holocene in Palau, and as Haberle $(2003: 252)$ notes, " $[\mathrm{t}]$ he interpretation of palaeoecological records from the Pacific Ocean region 
must clearly incorporate the influence of short-term climate variability on vegetation dynamics as a significant driving force of vegetation change during the mid to late Holocene."

This leaves Cyrtosperma chamissonis pollen as the strongest evidence for early human arrival in Palau. Athens and Ward (2001:171) report that since the Ngerchau core was located in an overgrown taro pond field, bioturbation processes might have moved the eight grains of Cyrtosperma pollen downward. As there was no evidence for disturbance or pollen types typical of later periods, and the pollen grains occurred well below ground surface $(290-292 \mathrm{~cm}, 347-349 \mathrm{~cm}$, and $472-474 \mathrm{~cm}$ ), bioturbation was deemed unlikely. However, a single grain of tapioca (Manihot esculenta), a historic introduction, was found in the Olbed-1 core (central Babeldaob) below a radiocarbon date of ca. $1300 \mathrm{cal}$. B.P. (Athens and Ward 1999:108), showing that introduced plant pollen can be displaced into older sediments despite evidence of bioturbational processes. Caution must attend cases such as Ngerchau, where sediment cores recovered from areas known to have been cultivated in late prehistoric/historic times contain pollen from introduced plants in older than expected contexts, until the findings are supported by additional paleoenvironmental or archaeological results.

In this regard, the basal Ulong deposit, like other archaeological sites associated with coherent sets of dated cultural remains such as burial caves and upland occupation sites (Fitzpatrick 2002, 2003; Welch 2002; Wickler 2002), has an age span of 2400-3000 cal. B.P. Critical reviews of radiocarbon dates from Palau and western Micronesia demonstrate that there is no convincing evidence in age determinations from cultural deposits for colonization much earlier than 3300 cal. B.P. (Clark 2004; Phear et al. 2003), although settlement of the Marianas at 36003500 cal. B.P. is often considered likely from individual radiocarbon results and the affinities of the oldest decorated pottery to ceramics from insular Asia and the Lapita assemblages in Oceania (Butler 1994; Intoh 1997). If the colonization of western Micronesia took place between 3500 and 3000 cal. B.P., as some archaeological and paleoenvironmental results now suggest (Clark 2004; Clark and Wright 2003a; Dodson and Intoh 1999), then the earliest cultural assemblage from Ulong may postdate initial Austronesian arrival by a few centuries.

Human use of Ulong began at 3000 cal. B.P. on a small beach in front of which lay a sheltered intertidal zone, and other old cultural deposits may be preserved in similar Rock Island locations where beach deposits were able to accumulate behind deep and protective limestone headlands. As the sand plain extended seaward, infilling the embayment and creating a coastal strip along the western edge of the island, occupation became more frequent and possibly permanent. Whereas grog-tempered middle ceramics were found in shovel tests and surface finds in other parts of Ulong (Clark and Wright 2003b), the basal calcareous-volcanic ceramics were found only in excavated units where the oldest beach deposit accrued. In stratigraphic terms, a possible boundary between intermittent and permanent/semi-permanent occupation was found at $100-135 \mathrm{~cm}$ depth, with a transition from calcareous-limey sands to silty organic sands, dating to ca. 24002000 cal. B.P. This is considerably earlier than the A.D. 1200-1600 age for permanent habitation of the Rock Islands proposed by Masse et al. (1984:114), suggesting that occupation of limestone islands was partly conditioned by the extent of sand-plain development and ability to tap the freshwater aquifer underlying 
prograding Holocene sediments. Built structures, including limestone platforms, walls, and a walk-in well, were associated with flange-rim ceramics dated to 950-550 cal. B.P., and Ulong was uninhabited, for reasons that require further research, when the shipwrecked crew of the Antelope arrived in 1783 (Keate 2000). In oral traditions, Ulong was an important center, which was depopulated after being defeated by forces from Ngemilis and Pelilieu (Osborne 1966:401403).

The Ulong material-culture assemblage contains local imports from the volcanic islands, including tuff abraders, worked ironstone, chert, and adzes made in andesitic-basaltic volcanic breccia. The ceramics were also made locally and brought to Ulong, and the pottery sequence-the first for the archipelagoshows clear evidence of temporal change. The oldest basal ceramics contain redslipped and burnished sherds with rare examples of lip impressing, incision, molding, and possible lime infilling, which are all traits reported from early assemblages from Island Southeast Asia and the Pacific. Beyond these simple and geographically widespread analogues, the Ulong decoration and rim forms appear different from either the Achugao or San Roque incised ceramics of the Marianas (Butler 1994), and particularly striking is the absence of early carinated vessels in Palau of the kind found in the Marianas, Southeast Asia, and west Pacific Lapita sites. The degree of ceramic differentiation supports a linguistic model featuring colonization of Palau, Yap, and the Marianas by distinct cultural groups from the Philippines and adjacent island groups (Blust 2000).

The most striking change in the Ulong ceramic sequence is the transition from basal to middle ceramics, with changes in vessel form, decoration, temper, and clay. These changes might result from the arrival of migrants with a different pottery tradition. In the Pacific there has been a tendency to correlate prehistoric ceramic change in the west Pacific with population migration or contact (Best 2002; Burley and Clark 2003; Spriggs 2003), even though the known pottery styles are not always homologous between migrant source and destination, which must be the logical and essential test of any population intrusion hypothesis based on ceramics (Adams 1979; Bedford and Clark 2001; Clark 2003). The suggestion that substantial pottery change could well derive from endogenous factors does not imply that long-distance voyaging and contact did not take place in prehistory, only that such events, unless of a sufficient magnitude or frequency, need not affect the stylistic basis of ceramic production within an archipelago. There is, as yet, no assemblage outside Palau that appears similar to the middle ceramics from Ulong, and an endogenous explanation for ceramic change should be the default position until ceramic or other material-culture evidence suggests otherwise.

In view of the relative abruptness and extent of ceramic change in the Ulong sequence, the most intriguing transition is the use of a calcareous-volcanic beachsand temper in basal ceramics to the growing dominance of grog temper by 2500 cal. B.P. through to the late prehistoric era. Two sediment cores document the movement of upland sediments to coastal lowlands on Babeldaob in the period 2450-2200 cal. B.P., indicating the onset of a major erosional episode as a result of terrace construction (Athens and Ward 1999:iv). Anthropogenic sediment mobilization would increase estuary and lagoon siltation, leading to extensive conversion of beachfronts to mangrove fringes. Mangrove forest covers just under 80 percent of the Babeldaob coastline (Athens and Ward 1999:13). These envi- 
ronmental effects would have diminished the number of beaches with hybrid volcanic-calcareous sands, and may have induced prehistoric potters to experiment with grog as a substitute for increasingly scarce beach sands. Further, the change to grog temper appears to have been associated with the use of a carbonaceous clay that was insufficiently oxidized during firing, resulting in a dark core when viewed in cross section. In middle ceramics the dark core is usually flanked by lighter colored layers, which suggests organic material was present in the raw clay (Rice 1987:334). A potential source is the Arai clay formation in the south and west of Babeldaob, consisting of interbedded clays, silty clays, and lignites, with fixed carbon yields of 10-32 percent (Corwin et al. 1956:263-267). The use of different temper and clay products by Palauan potters as a result of anthropogenic landscape change would have had stylistic and possibly technological consequences for ceramic production. Thus, while prehistoric ceramic change is generally ascribed to direct cultural influences, either exogenous or endogenous, the difference between basal and middle ceramics at Ulong is, at least in part, likely to represent resource adaptation as a result of human occupation and ongoing landscape change.

The Lapita dispersal and the colonization of east Polynesia are characterized increasingly as geographically widespread and time-constrained expansions of groups with shared cultural, biological, and linguistic traits (Anderson 2003; Green 2003; Pearthree and Di Piazza 2003). In contrast, western Micronesia appears anomalous, and a hypothesis featuring independent settlement of each archipelago by distinct cultural groups has long been favored by archaeologists and linguists (Blust 2000; Intoh 1997; Rainbird 1994). Setting aside the question of whether colonization of Palau, Yap, and the Marianas was isochronic or heterochronic, an early cultural diversity in western Micronesia implies sociolinguistic fragmentation during Austronesian expansion through the Philippines and adjacent areas. Further, the possession of navigation ability and sea craft required to reach western Micronesia suggests that maritime skills were widely dispersed among contemporary cultures of the region.

It is useful, therefore, to distinguish between two potential modes of Austronesian expansion. Austronesian movement into the thinly populated and intervisible Bismarck Archipelago-Solomon Islands and east into uninhabited Remote Oceania-which comprises more than 60 percent of the culture distributionfacilitated the rapid dispersal of the Lapita culture complex. Lapita dispersal represents, then, the progressive easing of environmental and particularly social constraints to migration during Austronesian expansion into the West Pacific. As Ravenstein (1889:288) noted in an influential paper, the most active episodes of migration occurred at locations whose "resources have only recently become available." In Island Southeast Asia the diversity and interaction among relatively populous migrant and indigenous groups, and the proximity of islands in the Sulu and Celebes Seas to mainland Asia, likely fostered a complex and culturally diverse Austronesian settlement history, embodied in the linguistic and materialculture differences of western Micronesia, although archaeological evidence regarding population size and the degree of cultural variability have yet to be established. Conceived this way, the scale and relative cultural uniformity of Lapita dispersal in Remote Oceania is atypical compared to the variegated pattern of Austronesian progress in Island Southeast Asia and western Micronesia. 


\section{ACKNOWLEDGMENTS}

Excavations were carried out with the permission of the governor of Koror, the Honourable John Gibbons, and the Bureau of Arts and Culture, and we are especially grateful to Vick Kanai (Director, Bureau of Arts and Culture) and Rita Olsudong (Head of Archaeology, Division of Cultural Affairs) for facilitating fieldwork. I thank Vince Blaiyok, Dino Mibuk, Lark Ngirkiklang, and Duncan Wright for helping with the excavations, and William Dickinson, John Chappell, and Andrew Christy for materials analysis. Simon Haberle provided useful references, and I thank Duncan Wright and Sarah Phear for commenting on an earlier draft. I thank three anonymous referees and the editor for their pertinent comments, which helped to improve the paper. Fieldwork and analyses was funded by a postdoctoral Australian Research Council grant, a Faculty of Arts Grant (ANU), and a Centre for Archaeological Research (CAR, ANU) New Initiative grant.

\section{REFERENCES}

Adams, W. Y.

1979 On the argument from ceramics to history: A challenge based on evidence from Medieval Nubia. Current Anthropology 20:727-744.

Anderson, A.

2003 Initial human dispersal in Remote Oceania: A pattern and explanation, in Pacific Archaeology: Assessments and Prospects: 71-84, ed. C. Sand. Les Cahiers de l' Archéologie en Nouvelle-Calédonie 15. New Caledonia.

Anderson, A., J. Chappell, G. Clark, and S. Phear

In press Comparative radiocarbon dating of pottery and charcoal samples from Babeldaob Island, Republic of Palau. Radiocarbon.

Athens, J. S., AND J. V. WARD

1999 The Holocene palaeoenvironment of Palau. Volume IV, Intensive Archaeological Survey for the Palau Compact Road, Babeldaob Island, Palau: Historic Preservation Investigations, Phase II. Report prepared for U.S. Army Corps of Engineers. International Archaeological Research Institute, Inc., Honolulu.

2001 Palaeoenvironmental evidence for early human settlement in Palau: The Ngerchau core, in Pacific 2000. Proceedings of the Fifth International Conference on Easter Island and the Pacific: 164-177, ed. C. M. Stevenson, G. Lee, and F. J. Morin. Easter Island Foundation and Bearsville Press.

2004 Holocene vegetation, savannah origins and human settlement of Guam. Records of the Australian Museum Supplement 29:15-30.

BedFord, S., ANd G. Clark

2001 The rise and rise of the incised and applied relief, in The Archaeology of Lapita Dispersal in Oceania: 61-74, ed. G. R. Clark, A. J. Anderson, and T. Vunidilo. Canberra: Pandanus Press, Australian National University.

Best, S.

1984 Lakeba: The prehistory of a Fijian Island. Ph.D. diss., University of Auckland, Auckland.

BEST, S. B.

2002 Lapita: A view from the east. New Zealand Archaeological Association Monograph 24.

Blust, R.

2000 Chamorro Historical Phonology. Oceanic Linguistics 39:83-122.

Burley, D. V., and J. T. Clark

2003 The archaeology of Fiji/Western Polynesia in the post-Lapita era, in Pacific Archaeology: Assessments and Prospects: 235-254, ed. C. Sand. Les Cahiers de l'Archéologie en Nouvelle-Calédonie 15. New Caledonia.

ButLer, B. M.

1994 Early prehistoric settlement in the Marianas Islands: New evidence from Saipan. Man and Culture in Oceania 10:15-38. 
Clark, G.

1999 Post-Lapita Fiji: Transformation in the mid-sequence. Ph.D. diss., Australian National University, Canberra.

2003 Shards of Meaning: Archaeology and the Melanesia-Polynesia distinction. Journal of Pacific History 38(2): 197-213.

2004 Radiocarbon dates for the Ulong site in Palau and implications for western Micronesian prehistory. Archaeology in Oceania 39:26-33.

Clark, G., and A. Anderson

2001 The pattern of Lapita settlement in Fiji. Archaeology in Oceania 36:77-88.

Clark, G., and D. Wright

2003a The colonisation of Palau: Preliminary results from Angaur and Ulong, in Pacific Archaeology: Assessments and Prospects: 85-94, ed. C. Sand. Les Cahiers de 1' Archéologie en Nouvelle-Calédonie 15. New Caledonia.

$2003 b$ Archaeological research on Ulong Island, Koror State, Republic of Palau. Unpublished report to the Palau Division of Cultural Affairs.

Corwin, C. G., C. L. Rogers, and P. O. Elmeuist

1956 Military Geology of Palau Islands, Caroline Islands. Intelligence Division, Office of the Engineer, Headquarters U.S. Army Far East.

Craib, J. L., and G. R. Mangold

1999 Storm in a test pit: Effects of cyclonic storms on coastal archaeological sites in western Micronesia, in Australian Coastal Archaeology: 299-306, ed. J. Hall and I. J. McNiven. Research Papers in Archaeology and Natural History 31. Canberra: ANH Publications.

Denham, T. P., S. G. Haberle, C. Lentfer, R. Fullagar, J. Field, M. Therin, N. Porch, and B.

WINSBOROUGH

2003 Origins of Agriculture at Kuk Swamp in the Highlands of New Guinea. Science 301 : 189193.

Desilets, M., J. Liston, And H. D. Tuggle

1999 Ceramic Analysis. Archaeological data recovery for the Compact Road, Babeldaob Island, Republic of Palau, in Volume V, Lab Analyses, Syntheses, and Recommendations: 181-231, ed. J. Liston. Draft report prepared for the U.S. Army Corps of Engineers, Pacific Ocean Division, Ft. Shafter, Hawai'i. International Archaeological Research Institute, Inc., Honolulu.

Devlin, B., K. Roeder, C. Otto, S. Tiobech, and W. Byerley

2001 Genome-wide distribution of linkage disequilibrium in the population of Palau and its implications for gene flow in Remote Oceania. Human Genetics 108:521-528.

Dickinson, W. R.

2004 Picture essay of Pacific island coasts. Journal of Coastal Research 20:1012-1034.

Dodson, J. R., and M. InTOH

1999 Prehistory and palaeoecology of Yap, Federated States of Micronesia. Quaternary International 59:17-26.

FitzPATRICK, S. M.

2002 AMS dating of human bone from Palau: New evidence for a pre-2000 B.P. settlement. Radiocarbon $44: 217-221$.

2003 Early human burials in the western Pacific: Evidence for a c. 3000 year old Occupation on Palau. Antiquity 77:719-731.

Fitzpatrick, S. M., W. R. Dickinson, and G. Clark

2003 A petrographic analysis of ceramics from Palau, Micronesia. Journal of Archaeological Science 30:1175-1184.

Gagan, M. K., E. J. Hendy, S. G. Haberle, and W. S. Hantoro

2004 Post-glacial evolution of the Indo-Pacific Warm Pool and El Niño-Southern Oscillation. Quaternary International 118-119:127-143.

Green, R. C.

1991 Near and Remote Oceania: Disestablishing Melanesia in culture history, in Man and a Half: Essays in Pacific Anthropology and Ethnobiology in Honour of Ralph Bulmer: 491-502, ed. A. Pawley. Auckland: Polynesian Society. 
GreEN, R. G.

2003 The Lapita horizon and traditions - Signature for one set of oceanic migrations, in Pacific Archaeology: Assessments and Prospects: 95-120, ed. C. Sand. Les Cahiers de l'Archéologie en Nouvelle-Calédonie 15. New Caledonia.

Haberle, S. G.

2003 Late quaternary vegetation dynamics and human impact on Alexander Selkirk Island, Chile. Journal of Biogeography 30:239-255.

Haberle, S. G., ANd M.-P. Ledru

2001 Correlations among charcoal records of fires from the past 16,000 years in Indonesia, Papua New Guinea and Central and South America. Quaternary Research 55:97-104.

INTOH, M.

1992 Pottery traditions in Micronesia, in Poterie Lapita et Peuplement: 67-82, ed. J. C. Galipaud. Nouméa: ORSTOM.

1997 Human dispersals into Micronesia. Anthropological Science 105:15-28.

IRwin, G.

1992 The Prehistoric Exploration and Colonisation of the Pacific. Cambridge: Cambridge University Press.

Keate, G.

2000 An Account of the Pelew Islands, Situated in the Western Part of the Pacific Ocean. Facsimile re[1789] production of the 3rd edition, in History of Micronesia: A Collection of Source Documents 15, Mostly Palau, 1783-1793, ed. R. Lévesque. Québec: Lévesque Publications.

KIRCH, P. V.

2000 On the Road of the Winds. An Archaeological History of the Pacific Islands before European Contact. Berkeley: University of California Press.

KIRCH, P. V., AND D. YEN

1982 Tikopia. The prehistory and ecology of a Polynesian Outlier. Bernice P. Bishop Museum Bulletin 238. Honolulu: Bishop Museum Press.

Liston, J.

1999 Archaeological Monitoring Plan and Research Design for Phase III Historic Preservation Investigations, Palau Compact Road. Prepared for Honolulu Engineering District, U.S. Army Corps of Engineers. International Archaeological Research Institute, Inc., Honolulu.

Liston, J., T. M. Mangieri, D. Grant, M. W. Kaschko, and H. D. Tuggle

1998 Archaeological data recovery for the Compact Road, Babeldaob Island, Republic of Palau. Historic Preservation Investigations, Phase II. Volume II: Fieldwork Reports. Prepared for Honolulu Engineering District, U.S. Army Corps of Engineers. International Archaeological Research Institute, Inc., Honolulu.

LUCKING, L. J.

1984 An archaeological investigation of prehistoric Palauan terraces. Ph.D. diss., University of Minnesota, Minneapolis.

Lum, J. K., AND R. L. CANN

2000 mtDNA lineage analyses: Origins and migrations of Micronesians and Polynesians. American Journal of Physical Anthropology 113:151-168.

Masse, W. B.

1989 The Archaeology and Ecology of Fishing in the Belau Islands, Micronesia, Part 1 and Part 2. Ann Arbor, MI: University Microfilms International.

1990 Radiocarbon dating, sea-level change and the peopling of Belau. Micronesica Supplement $2: 213-230$.

Masse, W. B., D. Snyder, And G. J. Gumerman

1984 Prehistoric and historic settlement in the Palau Islands, Micronesia. New Zealand Journal of Archaeology 6: 107-127

McPhail, M. K., G. S. Hope, and A. Anderson

2001 Polynesian plant introductions in the Southwest Pacific: Initial pollen evidence from Norfolk, in The Prehistoric Archaeology of Norfolk Island, Southwest Pacific: 123-134, ed. A. Anderson and P. White. Records of the Australian Museum Supplement 27.

ODA, S.

1981 The archaeology of the Ogasawara Islands. Asian Perspectives 24:111-138. 
OSBORnE, D.

1958 The Palau Islands: Stepping stones into the Pacific. Archaeology 11:162-171.

1966 The Archaeology of the Palau Islands. Bernice P. Bishop Museum Bulletin 230. Honolulu: Bishop Museum Press.

1979 Archaeological test excavations Palau Islands 1968-1969. Micronesica Supplement 1.

Pearthree, E., and A. Di Piazza

2003 An 'Archaic East Polynesian Assemblage' from the Phoenix and Line Archipelagos, in Pacific Archaeology: Assessments and Prospects: 327-336, ed. C. Sand. Les Cahiers de 1' Archéologie en Nouvelle-Calédonie 15. New Caledonia.

Phear, S., G. Clark, and A. Anderson

2003 A radiocarbon chronology for Palau, in Pacific Archaeology: Assessments and Prospects: 241-249, ed. C. Sand. Les Cahiers de l' Archéologie en Nouvelle-Calédonie 15. New Caledonia.

RAINBIRD, P.

1994 Prehistory in the northwest tropical Pacific: The Caroline, Mariana, and Marshall islands. Journal of World Prehistory 8:293-349.

RASSER, M. W., AND B. RIEGL

2002 Holocene coral reef rubble and its binding agents. Coral Reefs 21:57-72.

Ravenstein, E. G.

1889 The Laws of Migration. Journal of the Royal Statistical Society 52:241-305.

ReITH, T. M., AND J. Liston

2001 Archaeological data recovery at Ngermereues Ridge, Ngesaol, Koror, Republic of Palau. International Archaeological Research Institute Inc., Hawai'i.

RiCE, P. M.

1987 Pottery Analysis: A Sourcebook. Chicago: University of Chicago Press.

Rintaro, O.

2003 Prehistoric Austronesian fishing strategies: A tentative comparison between Island Southeast Asia and the Lapita Cultural Complex, in Pacific Archaeology: Assessments and Prospects: 191-201, ed. C. Sand. Les Cahiers de l' Archéologie en Nouvelle-Calédonie 15. New Caledonia.

SHutler, R., JR.

1999 The relationship of red-slipped and lime impressed pottery of the Southern Philippines to that of Micronesia and the Lapita of Oceania, in The Pacific from 5000 to 2000 B.P.: 521-529, ed. J.-C. Galipaud and I. Lilley. Paris: IRD.

SNYDER, D. M.

1989 Towards Chronometric Models for Palauan Prehistory: Ceramic Attributes. Ann Arbor, MI: University Microfilms International.

SNyder, D., AND B. M. Butler

1997 Micronesian Resources Study. Palau Archaeology. Archaeology and Historic Preservation in Palau. Micronesian Endowment for Historic Preservation, Republic of Palau, and U.S. National Park Service.

Southon, J., M. Kashgarian, M. Fontugne, B. Metivier, and W.W.-S. Yim

2002 Marine reservoir corrections for the Indian Ocean and Southeast Asia. Radiocarbon $44: 167-180$.

SPRIGgS, M.

2003 Post-Lapita evolutions in Island Melanesia, in Pacific Archaeology: Assessments and Prospects: 205-212, ed. C. Sand. Les Cahiers de 1' Archéologie en Nouvelle-Calédonie 15. New Caledonia.

Stevenson, J., And R. Dodson

1995 Palaeoenvironmental evidence for human settlement of New Caledonia. Archaeology in Oceania 30:36-41.

Stuiver, M., and T. H. Braziunas

1993 Modeling atmospheric ${ }^{14} \mathrm{C}$ influences and ${ }^{14} \mathrm{C}$ ages of marine samples to 10,000 B.C. Radiocarbon 35:137-189. 
Stuiver, M., AND P. J. Reimer

1993 Extended ${ }^{14} \mathrm{C}$ data base and revised CALIB $3.0{ }^{14} \mathrm{C}$ age calibration program. Radiocarbon $35: 215-230$.

TАKАYАMA, J.

1981 Early pottery and population movements in Micronesian prehistory. Asian Perspectives 24:1-10.

WELCH, D. J.

2001 Early upland expansion of Palauan settlement, in Pacific 2000: Proceedings of the Fifth International Conference on Easter Island and the Pacific: 179-184, ed. C. M. Stevenson, G. Lee, and F. J. Morin. Easter Island Foundation and Bearsville Press.

2002 Archaeological and palaeoenvironmental evidence of early settlement in Palau. Bulletin of the Indo-Pacific Prehistory Association 22:161-173.

WICKLER, S.

2001 The colonization of western Micronesia and early settlement of Palau, in Pacific 2000: Proceedings of the Fifth International Conference on Easter Island and the Pacific: 185-196, ed. C. M. Stevenson, G. Lee, and F. J. Morin. Easter Island Foundation and Bearsville Press.

2002 Terraces and villages: Transformation of the cultural landscape in Palau, in Pacific Landscapes: Archaeological Approaches in Oceania: 63-96, ed. T. Ladefoged and M. Graves. Easter Island Foundation and Bearsville Press.

Wickler, S., D. Welch, M. J. Tomonari-Tuggle, J. Liston, and H. D. Tuggle

1998 Intensive Archaeological Survey for the Palau Compact Road, Babeldoab Island, Palau. Historic Preservation Investigations Phase I, Vol. 1: Scope, Background, Results, Evaluation and Recommendations. Report prepared for U.S. Army Corps of Engineers. International Archaeological Research Institute, Inc., Honolulu. 


\section{APPENDIX A}

Appendix ia. XrF Major and Trace Element Analyses on Stone Artifacts from Ulong, Angaur Island, and Oikull

\begin{tabular}{|c|c|c|c|c|c|c|c|c|c|c|c|c|}
\hline $\begin{array}{l}\text { OXIDE/ } \\
\text { ELEMENT }\end{array}$ & PL-01 & PL-02 & PL-03 & PL-04 & PL-05 & PL-06 & PL-07 & PL -08 & PL -09 & $\mathbf{P L}-10$ & $\mathrm{PL}-11$ & $\mathrm{PL}-12$ \\
\hline $\mathrm{SiO}_{2}$ & 49.86 & 49.84 & 51.38 & 51.78 & 49.22 & 48.96 & 47.88 & 51.41 & 49.40 & 49.12 & 51.14 & 53.44 \\
\hline $\mathrm{Al}_{2} \mathrm{O}_{3}$ & 15.07 & 13.70 & 17.49 & 17.33 & 14.58 & 15.23 & 15.83 & 16.73 & 15.56 & 17.63 & 17.48 & 18.32 \\
\hline $\mathrm{CaO}$ & 8.94 & 9.94 & 8.80 & 9.29 & 10.13 & 9.66 & 9.25 & 8.22 & 9.87 & 9.82 & 9.84 & 7.59 \\
\hline $\mathrm{MgO}$ & 8.70 & 10.70 & 4.05 & 6.70 & 9.66 & 9.28 & 7.44 & 4.89 & 8.47 & 6.12 & 6.91 & 2.96 \\
\hline $\mathrm{MnO}$ & 0.12 & 0.15 & 0.11 & 0.08 & 0.18 & 0.13 & 0.11 & 0.14 & 0.14 & 0.13 & 0.14 & 0.14 \\
\hline $\mathrm{Na}_{2} \mathrm{O}$ & 3.36 & 1.62 & 1.76 & 2.12 & 1.99 & 2.51 & 3.70 & 3.01 & 2.18 & 1.23 & 1.48 & 3.10 \\
\hline $\mathrm{K}_{2} \mathrm{O}$ & 0.15 & 0.09 & 0.15 & 0.12 & 0.23 & 0.10 & 0.05 & 0.27 & 0.14 & 0.07 & 0.05 & 0.47 \\
\hline $\mathrm{TiO}_{2}$ & 0.43 & 0.34 & 0.66 & 0.49 & 0.43 & 0.46 & 0.46 & 0.51 & 0.46 & 0.49 & 0.43 & 0.54 \\
\hline $\mathrm{P}_{2} \mathrm{O}_{5}$ & 0.30 & 0.04 & 0.10 & 0.05 & 0.41 & 0.09 & 0.06 & 0.05 & 0.13 & 0.08 & 0.08 & 0.06 \\
\hline $\mathrm{SO}_{3}$ & 0.13 & 0.22 & 0.06 & 2.20 & 0.06 & 0.01 & 0.46 & 0.01 & 0.52 & 0.02 & 0.01 & 0.05 \\
\hline $\mathrm{Fe}_{2} \mathrm{O}_{3}$ & 6.81 & 8.88 & 10.51 & 7.10 & 7.86 & 9.32 & 8.44 & 7.87 & 8.67 & 8.97 & 8.82 & 8.15 \\
\hline $\mathrm{Sc}$ & 52.2 & 50.1 & 37.5 & 37.8 & 45.0 & 53.5 & 49.0 & 45.1 & 46.3 & 41.2 & 44.4 & 52.9 \\
\hline V & 122.6 & 284.3 & 249.4 & 230.1 & 194.0 & 206.2 & 165.3 & 140.7 & 290.3 & 105.1 & 81.3 & 87.1 \\
\hline $\mathrm{Cr}$ & 461.2 & 574.6 & 60.9 & 287.8 & 357.6 & 364.1 & 287.1 & 68.1 & 345.9 & 221.5 & 358.4 & 28.7 \\
\hline $\mathrm{Ni}$ & 48.5 & 151.9 & 30.2 & 72.4 & 81.9 & 64.6 & 54.0 & 19.4 & 73.0 & 25.0 & 86.3 & 58.5 \\
\hline $\mathrm{Cu}$ & 133.6 & 151.3 & 27.4 & 395.0 & 141.3 & 21.6 & 33.9 & 16.4 & 566.0 & 17.8 & 32.4 & 121.2 \\
\hline $\mathrm{Zn}$ & 23.3 & 54.3 & 39.5 & 23.0 & 90.9 & 31.9 & 18.2 & 27.4 & 33.2 & 21.4 & 17.2 & 23.2 \\
\hline $\mathrm{Ga}$ & 10.6 & 12.1 & 13.8 & 14.6 & 12.0 & 12.8 & 12.3 & 11.7 & 11.9 & 13.4 & 12.3 & 13.3 \\
\hline $\mathrm{Rb}$ & 1.3 & 0.9 & 1.8 & 0.9 & 1.7 & 0.5 & 0.5 & 3.6 & 2.5 & 0.5 & 0.3 & 3.9 \\
\hline $\mathrm{Sr}$ & 237.6 & 123.4 & 192.6 & 146.1 & 197.1 & 88.6 & 130.2 & 175.1 & 151.4 & 68.4 & 56.4 & 115.9 \\
\hline $\mathrm{Y}$ & 18.7 & 12.9 & 20.5 & 16.0 & 18.1 & 13.3 & 14.1 & 13.1 & 12.7 & 13.7 & 11.7 & 21.0 \\
\hline $\mathrm{Zr}$ & 15.8 & 21.8 & 43.0 & 25.1 & 21.7 & 23.9 & 24.1 & 20.4 & 31.0 & 17.7 & 14.3 & 9.9 \\
\hline $\mathrm{Nb}$ & 0.2 & 0.3 & 0.8 & 0.4 & 0.4 & 0.3 & 0.3 & 0.3 & 0.3 & 0.4 & 0.4 & 0.3 \\
\hline $\mathrm{Cs}$ & 8.1 & 0.1 & 1.0 & 0.8 & 4.7 & 2.1 & 1.6 & 16.8 & 0.2 & 3.4 & 3.4 & 33.9 \\
\hline $\mathrm{Ba}$ & 7.4 & 8.1 & 11.0 & 7.0 & 14.1 & 8.6 & 5.4 & 10.4 & 16.1 & 2.7 & 4.0 & 13.1 \\
\hline $\mathrm{La}$ & 1.5 & 0.8 & 1.1 & 1.5 & 2.5 & 0.4 & 0.8 & 1.2 & 0.4 & 3.0 & 1.4 & 1.7 \\
\hline $\mathrm{Ce}$ & 2.2 & 2.0 & 2.7 & 3.9 & 5.8 & 1.3 & 2.9 & 2.4 & 1.1 & 5.8 & 2.5 & 2.4 \\
\hline $\mathrm{Nd}$ & 3.2 & 2.5 & 3.1 & 3.8 & 5.3 & 2.2 & 3.8 & 2.6 & 1.8 & 5.5 & 2.7 & 3.1 \\
\hline $\mathrm{Sm}$ & 2.7 & 1.0 & 1.8 & 1.8 & 2.5 & 1.5 & 2.4 & 2.0 & 0.9 & 3.9 & 2.4 & 3.8 \\
\hline $\mathrm{Eu}$ & 2.7 & 0.4 & 1.1 & 1.0 & 1.9 & 1.3 & 2.0 & 1.7 & 0.4 & 3.4 & 2.7 & 3.9 \\
\hline $\mathrm{Gd}$ & 4.3 & 1.6 & 2.9 & 2.6 & 3.6 & 2.5 & 3.2 & 3.0 & 1.4 & 4.7 & 3.3 & 5.8 \\
\hline Dy & 5.9 & 2.0 & 4.1 & 3.6 & 4.3 & 3.4 & 4.2 & 4.3 & 1.9 & 5.6 & 5.0 & 9.9 \\
\hline $\mathrm{Er}$ & 8.5 & 1.4 & 4.1 & 4.0 & 4.9 & 4.8 & 5.7 & 6.1 & 1.4 & 8.5 & 7.8 & 16.2 \\
\hline $\mathrm{Yb}$ & 10.0 & 1.4 & 4.7 & 4.9 & 5.6 & 6.3 & 7.3 & 8.3 & 1.4 & 11.2 & 10.8 & 21.8 \\
\hline $\mathrm{Lu}$ & 11.7 & 0.2 & 3.7 & 4.5 & 5.3 & 6.5 & 8.2 & 9.2 & 0.2 & 13.1 & 13.7 & 24.7 \\
\hline $\mathrm{Hf}$ & 2.9 & 1.6 & 5.7 & 3.4 & 4.9 & 3.8 & 3.3 & 3.2 & 1.5 & 3.7 & 3.4 & 2.8 \\
\hline $\mathrm{Ta}$ & 1.6 & 0.4 & 2.5 & 1.7 & 3.0 & 2.0 & 1.7 & 1.6 & 0.3 & 2.3 & 2.1 & 1.5 \\
\hline $\mathrm{Pb}$ & 7.4 & 3.9 & 5.0 & 6.6 & 6.7 & 5.9 & 6.1 & 6.5 & 3.6 & 7.6 & 8.3 & 10.9 \\
\hline Th & 0.4 & 0.1 & 0.3 & 0.3 & 0.3 & 0.3 & 0.3 & 0.4 & 0.1 & 0.6 & 0.5 & 1.0 \\
\hline $\mathrm{U}$ & 1.7 & 0.1 & 0.6 & 0.4 & 1.5 & 1.2 & 1.9 & 1.0 & 0.1 & 1.3 & 1.2 & 2.1 \\
\hline
\end{tabular}

Note: Ulong: PL-01, PL-02. Angaur Island: PL-03, PL-04, PL-05. Oikull: PL-07, PL-08, PL-09, PL-10, PL-11. PL-12 is a sample of andesitic basalt outcropping above the traditional village site at Oikull. Loss on ignition (LOI) values were 3-6 percent. Ironstone artifacts elements were obtained with SEM-EDAX. 
Appendix ib. EDAX Results for Three Ironstone Artifacts EXPRESSED AS ATOMiC \%

\begin{tabular}{lcccccccccccc}
\hline UNIT & DEPTH & NA & MG & AL & SI & P & K & CA & TI & MN & FE & O \\
\hline TP.1 & $80-90$ & 0.2 & 0.2 & 6.2 & 7.2 & 0.2 & 0.0 & 0.3 & 0.1 & 0.0 & 30.6 & 55.3 \\
Unit 3 & $80-90$ & 0.1 & 0.0 & 4.4 & 3.8 & 0.2 & 0.0 & 0.2 & 0.1 & 0.0 & 38.1 & 53.2 \\
TP.1 & $110-120$ & 0.2 & 0.1 & 6.3 & 5.2 & 0.1 & 0.0 & 0.1 & 0.1 & 0.0 & 33.7 & 54.3 \\
\hline
\end{tabular}

Note: See text for details.

\begin{abstract}
In western Micronesia archaeological sites containing material-culture remains spanning millennia are rare. This paper reports one from Ulong Island in Palau, which is radiocarbon dated to 3000 cal. B.P. The pottery sequence was divided into three assemblages, each distinguished by distinct vessel forms and by the type and proportion of nonplastic temper inclusions. An abrupt transformation of the ceramic assemblage is tentatively dated to around 2400 cal. B.P., coincident with substantial landscape alteration on the main island where pottery was manufactured, indicating that anthropogenic activity may have constrained the raw materials available to prehistoric potters. There is a discontinuity in the sequence from 2000-1000 B.P. that might represent an hiatus in site use. Critical consideration of paleoenvironmental data pointing to human arrival at 4500-4300 cal. B.P. suggests, instead, that climatic events may be responsible for the observed palaeoecological changes. If so, then sites dating to 3300-3000 cal. B.P., such as Ulong, could well be among the oldest in western Micronesia. KeYwords: archaeology, Palau, colonization, culture sequence, western Micronesia.
\end{abstract}

